Canadian Journal of Fisheries and Aquatic Sciences

Canadian Science Publishing

Journal canadien des sciences halieutiques et aquatiques

\title{
Forecasting the magnitude and composition of phytoplankton blooms in a eutrophic lowland river (Rivière Yamaska, Que., Canada)
}

\begin{tabular}{|r|l|}
\hline Journal: & Canadian Journal of Fisheries and Aquatic Sciences \\
\hline Manuscript ID & cjfas-2016-0305.R2 \\
\hline Manuscript Type: & Article \\
\hline Complete List of Authors: & $\begin{array}{l}\text { Remmal, Yasmina; Environment and Climate Change Canada } \\
\text { Hudon, Christiane; Environment and Climate Change Canada } \\
\text { Hamilton, Paul; Research/Collections } \\
\text { Rondeau, Myriam; Environment and Climate Change Canada } \\
\text { Gagnon, Pierre; Environment and Climate Change Canada }\end{array}$ \\
\hline Keyword: & $\begin{array}{l}\text { RIVERS < Environment/Habitat, DIATOMS < General, EUTROPHICATION < } \\
\text { General, DISCHARGE, AUTOMATED MULTI-PROBES }\end{array}$ \\
\hline \multicolumn{2}{|c}{} \\
\hline
\end{tabular}

SCHOLARONE ${ }^{1 m}$

Manuscripts 


\section{Forecasting the magnitude and composition of phytoplankton} 2 blooms in a eutrophic lowland river (Rivière Yamaska, Que., 3 Canada)

4 Remmal $^{1}$, Y., C. Hudon ${ }^{1}$, P.B. Hamilton ${ }^{2}$, M. Rondeau ${ }^{1}$, P. Gagnon ${ }^{1}$

5

$6 \quad{ }^{1}$ Environnement et Changement climatique Canada - Région du Québec, Direction

7 générale des sciences et de la technologie, 105, rue McGill, $7^{\mathrm{e}}$ étage, Montréal (Québec)

8 H2Y 2E7, Canada

9 Email addresses: yasmina.remmal@mail.mcgill.ca; christiane.hudon@canada.ca;

10 myriam.rondeau@canada.ca; pierre.gagnon@canada.ca

$12{ }^{2}$ Musée canadien de la nature, 1740, chemin Pink, Gatineau (Québec) J9J 3N7, Canada

13 Email address: phamilton@mus-nature.ca

14 Corresponding author: C. Hudon; christiane.hudon@canada.ca

15 Submitted to Can. J. Fish. Aquat. Sci.

23 Running headline: Forecasting river plankton blooms

24 Keywords: Large river, Diatoms, Modelling, Discharge, Cyanobacteria, Algal blooms, 25 Nutrients, Automated multi-probes 


\section{Abstract}

28 The mechanisms controlling phytoplankton biomass and composition in the lower reach

29 of the eutrophic $\left(\mathrm{TP}>100 \mu \mathrm{g} \mathrm{P} \mathrm{L^{-1 } )}\right.$ Rivière Yamaska were studied over six consecutive

30 summers characterized by high (2008-2009) and low (2012-2013) discharge conditions.

31 In the lower river reach, periods of low river discharge favoured planktonic blooms $(>20$

$32 \mu \mathrm{g} \mathrm{Chl-a} \mathrm{L}^{-1}$ ) dominated by centric diatoms, in sharp contrast with numerous public

33 reports of simultaneous occurrence of cyanobacterial proliferation in the upstream lakes

34 and reservoirs. Daily cycles of hourly dissolved oxygen production were disrupted by

35 floods but resumed in the days following flow abatement and persisted under low

36 discharge conditions, suggesting that booms in the lower river reach resulted from local

37 production, rather than advection from upstream reservoirs. Motile, flagellate

38 chlorophytes and cryptophytes were more important under extreme high and low

39 discharge conditions whereas cyanobacteria co-occurred with centric diatoms under

40 intermediate discharge and highly illuminated conditions. Although the Rivière

41 Yamaska's flow remained sufficient to avoid cyanobacterial proliferation even under

42 lowest discharge conditions, our results suggest that increasing water residence time,

43 either through severe drought or river damming, will amplify the risk of toxic algal

44 blooms in the free flowing reaches of the lower Rivière Yamaska. 


\section{Résumé}

47 Les mécanismes contrôlant la biomasse et la composition du phytoplancton dans le cours

48 inférieur eutrophisé $\left(\mathrm{TP}>100 \mu \mathrm{g} \mathrm{P} \mathrm{L}^{-1}\right)$ de la rivière Yamaska, furent étudiés lors de six

49 étés consécutifs, caractérisés par des débits élevés (2008-2009) et faibles (2012-2013).

50 Dans le cours inférieur de la rivière, les périodes de faible débit favorisaient la

51 prolifération du plancton $\left(>20 \mu \mathrm{g} \mathrm{Chl-a} \mathrm{L}^{-1}\right)$ dominé par des diatomées centrales,

52 contrastant fortement avec les nombreux épisodes de prolifération de cyanobactéries

53 rapportés simultanément par le public dans les lacs et les réservoirs situés en amont. Les

54 cycles journaliers de production horaire d'oxygène dissous étaient interrompus lors des

55 crues, mais se rétablissaient dans les jours suivant la diminution du débit et persistaient

56 durant les périodes de faible débit, suggérant que les floraisons dans le cours inférieur de

57 la rivière résultaient de la production locale plutôt que de l'advection provenant des

58 réservoirs en amont. Les chlorophytes et cryptophytes flagellés mobiles étaient plus

59 importants sous les conditions de crue et d'étiage extrêmes tandis que les cyanobactéries

60 accompagnaient les diatomées centrales en conditions de débit intermédiaire et de forte

61 intensité lumineuse. Même si le débit de la rivière Yamaska est resté suffisamment élevé

62 pour éviter la prolifération de cyanobactéries même lors des débits les plus faibles, nos

63 résultats suggèrent que l'accroissement du temps de résidence, soit lors de sécheresses

64 sévères ou via la construction de barrages amplifiera le risque de floraisons de

65 cyanobactéries toxiques dans le cours principal de la basse Yamaska. 
Introduction

Anthropogenic activities use a great quantity of water, which is returned to water

68 bodies in a polluted state after agricultural, industrial or domestic use. Such

69 contamination has disrupted nutrient dynamics and increased the occurrence of

70 planktonic algal blooms in water bodies throughout the world (Conley et al. 2009;

71 Hoekstra et al. 2011; Pick 2016). Although the development and spread of algal blooms

72 are related to nutrient availability in most lakes (Hecky and Kilham 1988), plankton

73 development in large, nutrient-rich rivers is often controlled by physical factors such as

74 light intensity (i.e., precipitations and sunshine), water transparency (i.e., turbidity) and

75 residence time (i.e., discharge) (Søballe and Kimmel 1987). Water discharge and

76 turbidity were shown to control phytoplankton abundance in numerous temperate

77 lowland rivers in North America (Baker and Baker 1979; Hudon 2000; Phlips et al. 2007;

78 Hamilton et al. 2012), Europe (Descy et al. 1987; Kiss et al. 1994; Salmaso and Braioni

79 2008; Istvánovics and Honti 2011; Tavernini et al. 2011) and Australia (Hötzel and

80 Croome 1996). Light availability was also occasionally limiting phytoplankton

81 abundance in blackwater lowland rivers (Hammer 1965; Phlips et al. 2000; Hamilton et

82 al. 2012).

83 River plankton composition is commonly dominated by centric diatoms (e.g.,

84 Skeletonema potamos, Cyclotella spp., Discotella spp., Stephanodiscus spp.), small

85 flagellated Chlorophyta (Chlamydomonas spp., Monoraphidium spp.) and Cryptophyta

86 (Rhodomonas minuta [=Plagioselmis minuta], Cryptomonas erosa) tolerant to turbulence

87 and intermittent light (Kiss et al. 1994; Rojo et al. 1994; Hudon 2000). During drought

88 conditions, however, diatom-dominated blooms typical of median discharge conditions 
89 (Hötzel and Croome 1996) have been replaced by cyanobacterial blooms in the Murray

90 River (Australia) (Al-Tebrineh et al. 2012). In the hypereutrophic Nakdong River

91 (Korea), blooms are dominated by diatoms during wet periods and by toxic cyanobacteria

92 during dry seasons (Jeong et al. 2007). In both the Murray and the Nakdong rivers, the

93 severity of cyanobacterial blooms has been linked to the increase in water retention time

94 in reservoirs designed to sustain irrigation and human consumption during drought

95 periods (Mitrovic et al. 2011; Bowling et al. 2013). Increasing water temperature and the

96 frequency of extreme drought episodes coincident with climate change have also been

97 identified as drivers of the rising incidence of toxic cyanobacterial blooms (Paerl et al.

98 2011; Pick 2016).

A tributary of the St. Lawrence River that passes through farmland, the Rivière

100 Yamaska (Quebec) is notorious for its high nutrient content (Hudon and Carignan 2008).

101 Toxic cyanobacterial blooms are commonly reported in the upper lakes and reservoirs

102 (MDDEFP 2014), with resulting impairment to drinking-water sources basin-wide

103 (Rolland et al. 2005). Climate-change scenarios forecast increasing summer temperatures

104 coupled with higher incidence of drought periods for rivers draining the St. Lawrence

105 lowlands (CEHQ 2015), which could increase the frequency and severity of

106 cyanobacterial blooms. This study aimed at developing a model for forecasting plankton

107 blooms and species composition from environmental conditions in the lower reaches of

108 the Rivière Yamaska. The response of planktonic biomass and species composition to

109 discharge and water quality (SPM, TN, $\left.\mathrm{NO}_{2}-\mathrm{NO}_{3}, \mathrm{NH}_{4}, \mathrm{TP}, \mathrm{TDP}, \mathrm{DOC}\right)$ were examined

110 over six consecutive summers, coinciding with years of high $(2008,2009)$ and extremely

111 low $(2012,2013)$ discharge. 
We hypothesized that high nutrient concentration, periods of low river discharge

113 and high illumination would favour planktonic blooms ( $\left.>20 \mu \mathrm{g} \mathrm{Chl-} a \mathrm{~L}^{-1}\right)$. In addition, a

114 shift in plankton-species composition from diatoms to toxic cyanobacteria was expected

115 to occur under drought conditions, as a result of increased residence time and water

116 transparency. We also examined whether blooms in the lower reaches of the river were

117 produced locally or coincided with cyanobacterial occurrence reported in upstream

118 reservoirs, indicative of advection. Local plankton-production patterns under contrasting

119 discharge conditions were assessed using high-frequency (hourly) measurements of

120 dissolved $\mathrm{O}_{2}$ from automated probes. Advection of cyanobacteria from upstream

121 reservoirs to the lower river reaches was examined using reports of cyanobacterial

122 occurrence made by citizens to the MDDELCC (2008-2012) along the north branch of

123 the Rivière Yamaska (MDDELCC 2016, Fig. 1). This information allowed us to forecast

124 planktonic blooms under a range of discharge conditions and gain insights on the future

125 occurrence of potentially toxic cyanobacteria in the lower reaches of this heavily farmed

126 watershed.

\section{Material and methods}

\section{Study area}

The Rivière Yamaska (watershed area $4784 \mathrm{~km}^{2}$, average annual discharge 87

$\left.130 \mathrm{~m}^{3} \mathrm{~s}^{-1}\right)$ is located in southern Quebec and flows northwest over $160 \mathrm{~km}$ from its

131 headwaters at Lac Brome to its mouth at Lac Saint-Pierre (St. Lawrence River), draining 132268000 ha (56\% of watershed area) of farmland, including corn, soy and hog production

133 (Fig. 1). Both the main branch (Lac Brome) and the north branch (Lac Waterloo) of the 134 Rivière Yamaska alternate between fast-flowing and impounded lacustrine segments, the 
135 latter of which serve as sources of drinking water and recreational areas for local

136 communities. The population of the Yamaska watershed (257 500 inhabitants, Statistics

137 Canada 2011) is dispersed across 90 municipalities within the Montérégie administrative 138 region.

Between 2008 and 2012, cyanobacterial occurrences were signalled by the public

140 in 20 water bodies in the Montérégie administrative region, sampled analyzed and blooms

141 were confirmed $\left(\geq 20000\right.$ cells $\left.\mathrm{mL}^{-1}\right)$ by the Quebec Ministry of the Environment

142 (MDDEFP 2014; MDDELCC 2016). Recurrent blooms (i.e. reported over four, five or

143 six years) were sampled in 15 of those water bodies. Taxonomical analysis of water

144 samples revealed the occurrence of several potentially toxic genera, among which the

145 most common were Aphanizomenon, Dolichospermum, Microcystis and Woronichinia.

146 Toxin concentrations exceeding the standard for drinking water $\left(\leq 1.5 \mu \mathrm{g}\right.$ toxin $\mathrm{L}^{-1}$

147 microcystin LR equivalent toxicity, INSPQ 2005, Gouvernement du Québec 2016) were

148 measured in 17 Montérégie water bodies and 12 of those exhibited concentrations above

149 the threshold for recreational activities $\left(\leq 16 \mu \mathrm{g}\right.$ toxin $\mathrm{L}^{-1}$ Microcystin $\mathrm{LR}$ equivalent

150 toxicity, INSPQ 2005, MDDEFP 2014). Microcystin LR was also measured in the liver

151 of exploited fish species (Perca flavescens; $0.72-17.81 \mathrm{ng} \mathrm{g} \mathrm{tissue}^{-1}$ ) in four lakes of the

152 Yamaska watershed (Deblois et al. 2008).

153 Sampling and analyses

154 Water chemistry

155 Water quality data during summer (generally June to August or September in

156 2008-2013) were obtained from grab samples taken under the bridge of Route 132 at the

157 community of Yamaska $\left(46.0051^{\circ} \mathrm{N}-72.9101^{\circ} \mathrm{W}\right)($ Fig. 1, No. 1). Weekly water 
158 samples were collected just below the surface for analysis. Bulk (raw) water samples

159 were analyzed for total phosphorus (TP) and total nitrogen (TN). Suspended particulate

160 matter (SPM; APHA 1995) and planktonic chlorophyll-a (Environment Canada 2005)

161 were collected from filters (Whatman GF/F). Filtered water was analyzed for total

162 dissolved phosphorus (TDP), nitrites-nitrates $\left(\mathrm{NO}_{2}-\mathrm{NO}_{3}\right)$, ammonia nitrogen $\left(\mathrm{NH}_{4}\right)$ and

163 dissolved organic carbon (DOC) (Environment Canada 2005). TP and TDP

164 concentrations were measured by acid digestion followed by colorimetry with ammonium

165 molybdate. TN concentrations were determined using persulfate digestion with a

166 LACHAT Continuous Flow Quick-Chem 8000. $\mathrm{NO}_{2}-\mathrm{NO}_{3}$ was analyzed by nitrate-to-

167 nitrite reduction in a cadmium column prior to colorimetry. $\mathrm{NH}_{4}$ concentrations were

168 determined by colorimetry after the addition of sodium nitroprusside and phenate sodium.

169 DOC was oxidized to carbon dioxide by the addition of persulfate prior to infrared

170 detection (Shimadzu TOC-5000; Environment Canada 2005). Chlorophyll- $a$ was

171 determined spectrophotometrically using cold 95\% ethanol extraction following the

172 procedures of Wetzel and Likens (1991), a modified version of Lorenzen (1967)

173 (Environment Canada 2005).

174 Short-term variability (hourly average derived from a 15-minute or 30-minute

175 interval, June -September) of turbidity, conductivity and dissolved $\mathrm{O}_{2}$ as a response to

176 discharge variations was assessed. Measurements were made at 15-minute (2008 only) or

177 30-minute intervals by an automated YSI multi-probe (Model $6600 \mathrm{~V} 2$ ) moored $200 \mathrm{~m}$

178 downstream from the Route 132 bridge, where water-quality samples were taken. The

179 multi-probe was equipped with temperature, conductivity, turbidity, dissolved $\mathrm{O}_{2}$ and $\mathrm{pH}$

180 sensors; sensors were calibrated before mooring. Every two weeks, the multi-probe was 
181 retrieved, cleaned and verified, and data were downloaded. Calibration was verified again

182 in the laboratory after the final retrieval. Moorings were made during the summers of

1832008 (June 25 - Sept. 24), 2009 (June 29 - Sept. 4), 2011 (June 23 - Sept. 7) and 2012

184 (June 19 - July 28), covering a wide range of discharge conditions.

\section{Hydrological and meteorological data}

Daily discharge values for Rivière Yamaska were obtained (2008-2013) from the

187 Centre d'Expertise Hydrique du Québec (CEHQ 2014, Rivière Yamaska at Saint-

188 Hyacinthe, station no. 030345; watershed area: $3334 \mathrm{~km}^{2}$ ) (Fig. 1, No. 2). Additional

189 hydrometric information (mean depth, river width, wetted area, current speed) was

190 obtained at high- and low-river stages from gauging stations located downstream of

191 major impoundments (personal communication: Luc Gauthier, Direction de l'expertise

192 hydrique, MDDELCC, 675, René Lévesque est, Québec, Que.). Reports of cyanobacterial

193 occurrence in the upper part of the watershed were examined more closely for the north

194 branch of the Rivière Yamaska, which comprises five major lakes and dammed

195 impoundments: Lac Waterloo, Shefford-Vale, Granby, Farnham and Saint-Hyacinthe

196 (Table 1, Fig. 1, No. 2-6). Reservoir information (surface area, maximum volume,

197 watershed area) was obtained from CEHQ (2016). Land use data (Fig. 1) for 2010 was

198 obtained from the North American Land Change Monitoring System (NALCMS)

199 (available at https://landcover.usgs.gov/nalcms.php). Distribution of cropland in the St.

200 Lawrence River valley and distance $(\mathrm{km})$ between gauging stations and our sampling site

201 (Fig. 1, No. 1) were assessed using ArcGIS.

The above information was used to calculate reach length (the distance between

203 successive sites), transit time to the next reach and the cumulative advection time to the 
204 sampling site. The predominance of turbulent vs. laminar flow under low- and high-river 205 discharge conditions was roughly assessed by estimating Reynolds number (Re,

206 dimensionless), using the equation

$$
\operatorname{Re}=\rho v \mathrm{~L} / \mu
$$

208 where $\rho$ is the density of water $\left(1000 \mathrm{~kg} \mathrm{~m}^{-3}\right), v$ is the average current speed $\left(\mathrm{m} \mathrm{s}^{-1}\right), \mathrm{L}$ is 209 the hydraulic diameter of the river $\left(\mathrm{L}(\mathrm{m})=4 *\right.$ wetted section $\left(\mathrm{m}^{2}\right) /$ river width $\left.(\mathrm{m})\right)$ and $210 \mu$ is the dynamic viscosity of water at $20^{\circ} \mathrm{C}(0.001 \mathrm{~Pa} \mathrm{~s})$.

212 from Environment Canada (Meteorological Service of Canada, http://climat.meteo.gc.ca/)

213 for Saint-Hyacinthe Meteorological Station no. 7027361 (Fig. 1, No. 2). The effect of

214 precipitation on physical and chemical water quality was examined using the cumulative

215 precipitations at Saint-Hyacinthe over the three days prior to sampling.

216 Hourly values of photosynthetically active radiation (PAR, Li-Cor LI1400 and Li-

217 Cor LI1000 Data logger) were measured at the Station de Biologie des Laurentides

218 (Université de Montréal) located at Saint-Hippolyte (45.98854 -74.00583) (Fig. 1, No.

219 8). Light intensity measurements (mean hourly PAR values, $\mu \mathrm{mol} \mathrm{m} \mathrm{m}^{-2}$ ) averaged for 220 the three days prior to sampling (14 hours of daylight) were deemed to be an adequate 221 proxy for illumination in the lower Yamaska watershed, given that summer weather 222 patterns travel along the St. Lawrence River valley in a north-easterly direction. 
$\left.225^{1}\right)$ and SPM $\left(\mathrm{mg} \mathrm{L}^{-1}\right)$ concentrations $\left(\mathrm{k}^{2}=0.28 *\left(\mathrm{SPM}^{0.44}\right) *\left(\mathrm{DOC}^{0.63}\right)\right.$; Hudon, unpubl. 226 data).

\section{Phytoplankton composition and abundance}

Phytoplankton biomass and species composition of samples from the lower

229 reaches of the Rivière Yamaska (Fig. 1, No. 1) collected simultaneously with water

230 chemistry were preserved with acidified Lugol's solution prior to their analysis at the

231 Canadian Museum of Nature (Ottawa, Ontario). Phytoplankton was identified to the

232 lowest possible taxonomic level and enumerated using modified sedimentation chambers

233 (Hamilton et al. 2002). Aliquots of 0.5 to $4 \mathrm{~mL}$ were settled and examined with a Leica

234 DMR compound microscope using phase-contrast and bright-field optics; enumerations

235 were carried out on random transects scanned across the settling chamber at $200 \times$ or

$236400 \times$, and $800 \times$. The larger and often rarer taxa were enumerated by examining either

237 half or the complete chamber. Diatom identifications were verified from acid-cleaned

238 frustules on permanently mounted slides with Naphrax for light microscope examination.

239 In addition, specimens were dried on aluminum foil and mounted with double-sided

240 carbon tape on aluminum stubs for scanning electron microscopy examination. Taxa were

241 identified using the monographs of Hüber-Pestalozzi (1938, 1961, 1968), Prescott (1951),

242 Findlay and Kling (1979), Germain (1981), Krammer and Lange-Bertalot (1986-1991),

243 Anagostidis and Komarek (1988), Ettl and Gärtner (1988) and Compère (1989), among

244 others (for a complete list, see Hamilton et al. 1997). All taxa enumerated are catalogued

245 in a photomicrograph collection associated with this study held at the Canadian Museum

246 of Nature. A voucher sample collection from this study (2008-2011) is archived in the

247 Canadian Museum of Nature (CANA 85711-85732, 85822-85848). Plankton abundance 
248 measurements included cell density and biomass. The total volume of each taxon was

249 calculated from the average dimensions measured on numerous specimens if the taxon

250 was common, or one specimen if rare using one of seven geometrical shapes (sphere,

251 ellipsoid, cylinder, cone, double cone, rectangular box, prism on parallelogram-base)

252 (Hillebrand et al. 1999; Gosselain and Hamilton 2000). The total biovolume of

253 phytoplankton was converted to wet weight assuming a density of 1.

Episodes of cyanobacterial occurrence reported by the public throughout the

255 Yamaska watershed (2008-2012) were sampled, identified and compiled into a database

256 (MDDELCC 2016). The database comprised for each date, the location (Lat, Long) and

257 abundance (no. of cells $\mathrm{L}^{-1}$ ) of each cyanobacterial genus occurring at each site. Episodes

258 reported in the upper reaches (Fig. 1, No. 2 and 3) and along the north branch of the

259 Rivière Yamaska (Fig. 1, No. 4-6) in August and September 2009 were used to compare

260 the timing and composition of cyanobacterial occurrence between successive river

261 reaches down to our study site (Fig. 1, No. 1), indicative of downstream advection.

\section{Statistical analyses}

Relationships between plankton biomass and environmental variables were

264 explored using Spearman correlations. The delay between changes in discharge and the

265 ensuing plankton blooms was estimated from the correlation (Pearson r) between

266 chlorophyll- $a$ and mean Q over previous days, with increasing lag periods between two

267 and seven days. Groups of taxa showing a high relative abundance at the same time were

268 identified from a cluster analysis of the relative abundance of major taxa through time,

269 using the Lance and Williams nonmetric coefficient as a dissimilarity measure for

270 flexible-beta clustering (SAS/STAT 13.1, Cluster procedure). This dissimilarity measure 
271 was selected because the resulting clusters represented groups of taxa dominating

272 plankton assemblages (i.e., representing a high proportion of total biomass) in the same

273 samples at the same time.

The relationships between plankton biomass (Chl- $a$ ) and water-quality variables

$275\left(\mathrm{SPM}, \mathrm{NO}_{2}-\mathrm{NO}_{3}, \mathrm{NH}_{4}, \mathrm{DOC}, \mathrm{TP}, \mathrm{TDP}\right)$ were assessed using principal components

276 analysis (PCA) on log-transformed variables. The influence of environmental variables

277 on water chemistry was then evaluated by plotting and calculating the correlation

278 (Pearson $r$ ) between PCA axes and $\log _{10}$-transformed mean river discharge, cumulative

279 precipitation and mean PAR (all, three days prior to sampling). Time-series data were

280 smoothed by calculating a three-hour moving average.

281 The critical discharge and light conditions yielding different planktonic

282 chlorophyll- $a$ concentrations were modelled using a regression tree analysis (De'ath and

283 Fabricius 2000) implemented with procedure HPSPLIT from SAS/STAT, version 13.1

284 (SAS Institute).

\section{Results}

\section{Hydrological and environmental characteristics of the Rivière Yamaska}

Hydrometric measurements taken downstream of five north branch

288 impoundments 50.5-164 km upstream of our study site revealed the high range in current

289 speed and residence time experienced in each river section under high- and low-river

290 stages (Table 1). For example, at the station located downstream of Saint-Hyacinthe's

291 dam (Fig. 1, No. 2), mean current speed varied from 0.08 to $1.6 \mathrm{~m} \mathrm{~s}^{-1}$ over the range of

292 river discharge $\left(2.57-755 \mathrm{~m}^{3} \mathrm{~s}^{-1}\right)$, resulting in transit times between 7.4 and 0.4 days 
293 (Table 1) to our sampling site in the lower Rivière Yamaska (Fig. 1, No. 1). Even under 294 the lowest discharge conditions, river-flow dynamics at all sites were dominated by 295 turbulent forces, as shown by the very high Reynolds number values $\left(\geq 0.09 \times 10^{6}\right.$, Table 296 1). Daily hydrological conditions in the Rivière Yamaska at Saint-Hyacinthe (Fig. 1, 298 No. 2) during the summers (June 1 - Sept. 30) of 2008-2013 exhibited a large degree of 299 short-term (day-to-day) variability and also differed markedly between years (Fig. 2).

300 Summer discharge at Saint-Hyacinthe ranged from a minimum daily base flow of $2.5 \mathrm{~m}^{3}$ $301 \mathrm{~s}^{-1}$ (Sept. 1, 2012) to a maximum value of $730 \mathrm{~m}^{3} \mathrm{~s}^{-1}$ (Aug. 29, 2011). Discharge showed 302 significant differences among years, with exceptional drought conditions in 2012 and $3032013\left(\mathrm{Q}<15 \mathrm{~m}^{3} \mathrm{~s}^{-1}\right)$ and comparatively wet summers in 2008 and $2009\left(\mathrm{Q}>47 \mathrm{~m}^{3} \mathrm{~s}^{-1}\right)$ 304 (Table 2). Light intensity showed an inverse pattern, with significantly higher 305 illumination in 2011-2013 (PAR $\left.>750 \mu \mathrm{mol} \mathrm{m}^{-2} \mathrm{~s}^{-1}\right)$ than in 2008-2010 $\left(\leq 600 \mu \mathrm{mol} \mathrm{m}^{-2}\right.$ $\left.306 \mathrm{~s}^{-1}\right)$ (Table 2). Daily precipitation also tended to be lower in $2011-2013(<2.5 \mathrm{~mm})$ than 307 in 2008-2010 (>3 mm), albeit without significant difference among years. Not 308 surprisingly, mean daily discharge was positively correlated with mean daily precipitation $309(\mathrm{r}=0.86, \mathrm{~N}=6, \mathrm{p}($ one-tailed $)=0.01)$ and negatively correlated with mean hourly PAR $310 \quad(\mathrm{r}=0.77, \mathrm{~N}=6, \mathrm{p}($ one-tailed $)=0.04)$

312 related to discharge and climatic conditions (Table 3). As anticipated, TP (106-142 $\mu \mathrm{g}$ P $\left.313 \mathrm{~L}^{-1}\right)$ and TDP $\left(35-57 \mu \mathrm{g} \mathrm{P} \mathrm{L}^{-1}\right)$ concentrations were high at all times (Table 3$)$. The wet 314 summer of 2008 showed the lowest water temperature, SPM concentration and turbidity, 315 but the highest DOC concentrations of all years. Conversely, summers of low discharge 
316 coincided with higher average water temperature $\left(>24^{\circ} \mathrm{C}\right)$ compared to years of high

317 discharge $\left(<22.5^{\circ} \mathrm{C}\right)$. In addition, the dry, sunny summer of 2012 coincided with

318 minimum concentrations of $\mathrm{TN}, \mathrm{NO}_{2}-\mathrm{NO}_{3}, \mathrm{NH}_{4}$, and $\mathrm{DOC}$, and the highest temperature,

319 turbidity and SPM concentrations of all years. Light-extinction coefficient always

320 remained high $\left(4.6-6.6 \mathrm{~m}^{-1}\right)$ (Table 3$)$, yielding a euphotic depth (Zeu, $\geq 1 \%$ of incident

321 light intensity) of about $1 \mathrm{~m}$. Given an estimated drop in mean river depth ( $\mathrm{Zt})$ from 3 to

$3221 \mathrm{~m}$ over the range of discharge that we sampled, $\mathrm{Zeu} / \mathrm{Zt}$ ratio would rise from $\approx 0.3$ (high

323 discharge in 2008) to $\approx 0.9$ (low discharge in 2012). Dropping discharge thus exposes

324 phytoplankton to slower current, longer residence time, shallower depth and higher light

325 intensity, yielding longer advection time from upstream reservoirs, yet more favourable

326 growth conditions (high light, low turbulence) for local phytoplankton.

\section{Phytoplankton biomass and species composition}

In contrast with environmental variables, which exhibited notable differences

329 between years of contrasting discharge, neither phytoplankton cell biomass nor

330 chlorophyll- $a$ concentration in the lower Rivière Yamaska showed any significant

331 difference between years, owing to the large short-term (within-year) variability (Table 4,

332 Fig. 2). Plankton biomass showed a "boom and bust" pattern over wet summers (2008,

333 2009) and tended towards higher, more-stable values during dry summers (Table 4, Fig.

334 2). Bloom concentrations ( $\left.>20 \mu \mathrm{g} \mathrm{Chl-} a \mathrm{~L}^{-1}\right)$ were observed for 35 of the 60 samples

335 taken over the six summers of our study.

337 concentrations $(\mathrm{r}=0.75, \mathrm{p}<0.001, \mathrm{~N}=54)$. Both cell biomass and chlorophyll- $a$ were

338 negatively correlated with discharge $(\mathrm{r}=-0.50, \mathrm{p}<0.001$ and $\mathrm{r}=-0.70, \mathrm{p}<0.001$, 
339 respectively, $\mathrm{N}=54)$ and less strongly with precipitations $(\mathrm{r}=-0.44, \mathrm{p}<0.001$ and $\mathrm{r}=$

$340-0.40, \mathrm{p}<0.05$, respectively, $\mathrm{N}=57$ ), likely resulting from the indirect relationship

341 between precipitation and discharge. In contrast, neither indicator of plankton abundance

342 showed any significant correlation with water chemistry (TP, $\mathrm{NH}_{4}, \mathrm{NO}_{2}-\mathrm{NO}_{3}, \mathrm{DOC}$ and

343 SPM concentrations).

Phytoplankton species composition over the 2008-2013 period was generally

345 dominated by diatoms (47-84\% of total biomass) (Table 4, Fig. 3), with a smaller

346 proportion of chlorophytes (9-22\%) and other algae. Chrysophytes (0.7-10\%),

347 cryptophytes (3-20\%) and pyrrhophytes (1-14\%) represented variable proportions of the

348 total biomass among years (Fig. 3). Diatoms represented the bulk ( $\geq 60 \%)$ of biomass in

$3492008-2011$, but were equalled by other taxonomical groups $(\approx 50 \%$ of total biomass $)$

350 during the dry summers of 2012 and 2013 (Fig. 3). The highest abundance of

351 cyanobacteria was observed in 2010, during which seven out of the 11 samples

352 comprised $>1$ million colonies $\mathrm{L}^{-1}$. No monthly or temporal trend indicative of a seasonal

353 succession in phytoplankton composition could be detected.

354 Five taxa of centric diatoms (Aulacoseira granulata, Skeletonema potamos,

355 Stephanodiscus parvus, Cyclotella meneghiniana and Discotella stelligera (=Cyclotella

356 stelligera)) constituted the bulk of cell biomass over most years (Table 4). Other diatoms

357 primarily comprised benthic pennate forms (Fragilaria spp., Navicula spp., Nitzschia

358 spp., Ulnaria spp.), which represented $>5 \%$ of total biomass during wet years. The

359 balance of biomass was associated with sporadically occurring taxa over the years, such

360 as Carteria spp. and other chlorophytes (2008, 2011), various cyanobacteria

361 (2009-2011), Cryptomonas erosa (2010, 2011, 2013) and Peridinium (2010, 2013) 
362 (Table 4). The planktonic flora of the summer of 2013 showed an unusually high biomass 363 of other small flagellate taxa such as Chlamydomonas spp. and Pteromonas aculeata364 taxa seldom observed over previous years.

The co-occurrence of most common taxa was determined from a cluster analysis 366 carried out on their relative abundance, highlighting four major clusters (Fig. 4). The first

367 cluster was formed by the dominant group of centric (all but Ulnaria spp.) diatoms

368 (Stephanodiscus parvus, Skeletonema potamos, Cyclotella meneghiniana, Discotella

369 stelligera) representing the bulk of biomass in most samples. Cluster II included taxa that

370 commonly occurred, but were less abundant than those from the previous group. Cluster

371 II was characterized by diatoms (Aulacoseira granulata, Nitzschia spp. and Navicula

372 spp.) and flagellated Chlorophyta (Pediastrum spp., Scenedesmus spp., Chlamydomonas

373 spp.), Euglenophyta (Phacus spp.), Cryptophyta (Cryptomonas erosa) and Pyrrhophyta

374 (Peridinium spp.). Cyanobacteria (Aphanizomenon spp., Dolichospermum spp. and other

375 cyanobacteria) exclusively formed Cluster III, a commonly occurring group, but with

376 generally low biomass. Finally, Cluster IV included sporadically occurring yet

377 occasionally abundant taxa, such as various Chlorophyta (Actinastrum spp., Carteria

378 spp., Closterium spp., Cosmarium spp., Monoraphidium spp., Pteromonas aculeata),

379 Pyrrhophyceae (Gymnodinium spp.), Chrysophyta and assorted diatoms (Fragilaria spp., 380 Melosira varians).

\section{Relationships between plankton biomass and environmental conditions}


385 was positively correlated with DOC $(\mathrm{r}=0.72)$ and all dissolved nutrients, including TDP

$386(\mathrm{r}=0.83), \mathrm{NH}_{4}(\mathrm{r}=0.70)$ and $\mathrm{NO}_{2}-\mathrm{NO}_{3}(\mathrm{r}=0.65)$ and negatively correlated with

387 chlorophyll- $a(\mathrm{r}=-0.75)$. This is indicative of agricultural surface runoff. In contrast, the

388 second principal component (25.0\% of total variance) exhibited strong positive

389 correlations with SPM $(r=0.91)$ and TP $(r=0.83)$. These correlations are indicative of

390 the effects of entrainment of phosphorus-rich particles eroded from the watershed and/or

391 resuspended from the river bed.

The first principal component was positively correlated with discharge, $(\mathrm{r}=0.72$,

$393 \mathrm{p}<0.001, \mathrm{~N}=50$ ) (Fig. 5B), suggesting that increasing runoff induced both the rise in

394 dissolved nutrients and the coincident drop in chlorophyll- $a$. Planktonic chlorophyll- $a$ at

395 our sampling site (Fig. 1, No. 1) showed a strong negative correlation with mean daily

396 discharge at Saint-Hyacinthe (Fig. 1, No.2); discharge chlorophyll- $a$ correlations

397 calculated with a lag-time between two $(r=-0.65)$ and seven days $(r=-0.70)$ were all

398 significant, but was highest with a three-day lag $(\mathrm{r}=-0.74, \mathrm{p}<0.001, \mathrm{~N}=54)$. The lesser

399 correlation values recorded between the first principal component and PAR $(r=-0.57, p$

$400<0.001, \mathrm{~N}=50)$ and with precipitations $(\mathrm{r}=0.49, \mathrm{p}<0.001, \mathrm{~N}=47)$ (not shown) could

401 result from the indirect relationships between sunny weather, precipitation and discharge.

402 On three dates (July 15, 2009, August 6 and 13, 2008) that coincided with samples taken

403 during high discharge conditions $\left(>120 \mathrm{~m}^{3} \mathrm{~s}^{-1}\right)$ (Fig. 5B), plankton biomass was low $(<3$

$404 \mu \mathrm{g} \mathrm{Chl}-a \mathrm{~L}^{-1}$ ) and stood out as maximum values of Component I (i.e., high TDP, DOC,

$405 \mathrm{NO}_{2}-\mathrm{NO}_{3}$ and $\mathrm{NH}_{4}$ ). In contrast, sampling on several dates in June and July 2012 (June

40626 , July 3, 10 and 23) occurred during low discharge $\left(<15 \mathrm{~m}^{3} \mathrm{~s}^{-1}\right)$ conditions and yielded

407 high plankton biomass (15-35 $\mu \mathrm{g}$ Chl- $\left.a \mathrm{~L}^{-1}\right)$, corresponding to low Component I (i.e., 
408 low TDP, DOC, $\mathrm{NO}_{2}-\mathrm{NO}_{3}$ and $\mathrm{NH}_{4}$ ) values (Fig. 5B). In summary, variations in

409 planktonic chlorophyll- $a$ were better explained by changes in discharge conditions than

410 by nutrient concentrations, which were in excess at all times. The short-term sequence of

411 events that illustrate the effects of discharge variations on $\mathrm{O}_{2}$ production by local

412 plankton, chlorophyll- $a$ and water quality will be examined below in more detail.

\section{Effects of short-term variability in discharge on planktonic $\mathrm{O}_{2}$ production}

414 The short-term response of local phytoplankton to changes in discharge and 415 turbidity was examined through the daily variations of dissolved $\mathrm{O}_{2}$ concentration. High

416 and variable discharge in August 2008 (Fig. 6A) contrasted with low but stable discharge

417 in June 2012 (Fig. 6B).

In 2008, three peaks in discharge were observed on August 4, 8 and 10, after

419 which discharge dropped and rose again slightly on August 20 (Fig. 6A). Turbidity

420 followed a similar pattern. During the flood event, dissolved $\mathrm{O}_{2}$ concentrations showed

421 no daily cycles and remained at around $80 \%$ saturation. After discharge receded (August

422 15), planktonic $\mathrm{O}_{2}$ production started rising and exhibited daily cycles in phase with

423 daylight. Over the same period, chlorophyll- $a$ concentration rose from $<2 \mu \mathrm{g} \mathrm{Chl-} a \mathrm{~L}^{-1}$

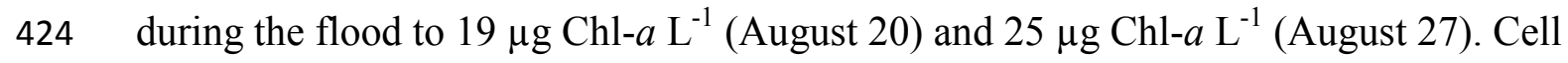

425 biomass followed the same pattern as chlorophyll- $a$ concentration, rising from 167 to

4261000 (August 20) and 3000 (August 27) $\mu \mathrm{g} \mathrm{L}^{-1}$. Interestingly, the lesser rise in discharge

427 observed on August 20 introduced some irregularity, but it did not interrupt the daily

428 cycles of $\mathrm{O}_{2}$ production, thereby maintaining the rise in planktonic biomass. 
In contrast, low discharge conditions were observed in 2012, with very slight rises

430

431

432

433

434 (from 35 to $15 \mu \mathrm{g} \mathrm{Chl}-a \mathrm{~L}^{-1}$ ) were observed, coincident with overcast and intermittent

435 rain conditions, bringing a slight rise in discharge (from 5.2 to $33 \mathrm{~m}^{3} \mathrm{~s}^{-1}$ ) on June 29 (Fig.

436 6B). Over the same period, plankton biomass dropped from 2600 (June 26) to $\approx 800 \mathrm{mg}$

$437 \mathrm{~m}^{-3}$ (July 3 and 10). Sunny conditions returned between July 3 and 10, with stable

438 discharge and chlorophyll- $a$ concentrations $\left(18 \mu \mathrm{g} \mathrm{Chl-} a \mathrm{~L}^{-1}\right)$ and $\mathrm{O}_{2}$ cycles showing an

439 upward trend towards saturation. Overall, periods of low and stable discharge coincided

440 with relatively high plankton biomass and sustained daily $\mathrm{O}_{2}$ production cycles, which

441 were modulated by variations of incident light intensity.

\section{Is there a correspondence between cyanobacterial occurrence in upstream}

443 reservoirs and lower river reaches?

448 in Farnham and 3 days in Saint-Hyacinthe (Fig. 1 No. 2-6, Table 1). Lac Waterloo

449 episodes were dominated by Microcystis, whereas those occurring in downstream

450 impoundments were characterized by Woronichinia and a co-occurrence of either
In the north branch of the Rivière Yamaska, cyanobacterial occurrence was reported by citizens or organisms to MDELCC at numerous sites and dates over the 2008-2012 period (Table 1). Cyanobacteria were reported in variable abundance over 26 days in Lac Waterloo, 14 days in the Réservoir Choinière, 39 days in Lac Boivin, 6 days Aphanizomenon (in Réservoir Choinière) or Microcystis further downstream (Table 1). In 
452 contrast, blooms at our sampling site in the lower reach of the river (Fig. 1, No. 1) were

453 generally dominated by diatoms and other algae, with a small cyanobacterial biomass

454 (Fig. 3, Table 4).

The timing of cyanobacterial occurrence was examined more closely for the

456 months of August and September 2009, during which period they were reported at

457 several locations in all the impoundments of the north branch of the Rivière Yamaska.

458 Cyanobacterial occurrence (listed here in order according to their location downstream)

459 was reported in Lac Waterloo (August 11, 2009), Réservoir Choinière (August 27), Lac

460 Boivin (August 5, 13, 20 and 26, September 2, 8, 16, 24 and 29), Farnham (August 24

461 and 28, September 10) and Saint-Hyacinthe (August 21, 24 and 28, September 10). No

462 pattern could be detected between the timing or magnitude of cyanobacterial episodes

463 among sites, or with respect to hydrological conditions. Since advection time between

464 these reaches is generally less than one day (Table 1), the general lack of pattern

465 suggested that cyanobacterial episodes in different reservoirs/lakes did not stem from

466 advection between reaches but were stimulated by favourable environmental conditions

467 in different parts of the watershed.

There was no correspondence between the dominant species or total biomass of

469 cyanobacteria reported near Saint-Hyacinthe (August 21, 24 and 28, September 10, 2009)

470 and those measured at our study site $50 \mathrm{~km}$ downstream (Table 1). In terms of

471 composition, however, it is worthy of notice that, out of the 56 samples collected in

$472 \quad 2008-2013$ at our sampling site, Woronichinia was recorded in only two samples taken in

473 August 2009 (12 and 26), and in very small numbers. Given the low discharge at Saint-

474 Hyacinthe in August and September 2009 (median $11.5 \mathrm{~m}^{3} \mathrm{~s}^{-1}$, range $3.7-117.2 \mathrm{~m}^{3} \mathrm{~s}^{-1}$ ), 
475 travel time from the Saint-Hyacinthe dam to our study site could take up to 7 days (Table $4761)$.

477 Forecasting biomass and composition from discharge and light conditions

A combination of discharge and light conditions yielded four groups of

479 chlorophyll- $a$ concentrations in a binary model that explained $59 \%$ of the total variance in 480 our data set (Fig. 7). Mean chlorophyll- $a$ concentration was lowest $\left(6.4 \mu \mathrm{g} \mathrm{Chl-} a \mathrm{~L}^{-1}\right)$ at high discharge $\left(\geq 44 \mathrm{~m}^{3} \mathrm{~s}^{-1}\right)$. Lowest discharge conditions $\left(<15 \mathrm{~m}^{3} \mathrm{~s}^{-1}\right)$ yielded

482 intermediate chlorophyll- $a$ concentrations $\left(23.3 \mu \mathrm{g}\right.$ Chl- $\left.a \mathrm{~L}^{-1}\right)$. Maximal chlorophyll- $a$ 483 concentration $\left(\right.$ mean $\left.=51.6 \mu \mathrm{g} \mathrm{Chl}-a \mathrm{~L}^{-1}\right)$ were reached under intermediate discharge $484 \quad\left(15-43 \mathrm{~m}^{3} \mathrm{~s}^{-1}\right)$ and high $\left(\geq 783 \mu \mathrm{mol} \mathrm{m}^{-2} \mathrm{~s}^{-1}\right)$ illumination (Fig. 7); incident light $<783$ $485 \mu \mathrm{mol} \mathrm{m} \mathrm{m}^{-2} \mathrm{~s}^{-1}$ yielded a lower $\left(27.6 \mu \mathrm{g}\right.$ Chl- $\left.a \mathrm{~L}^{-1}\right)$ mean chlorophyll- $a$ concentration. 486 Plankton biomass thus appeared primarily controlled by discharge, with a small influence 487 of light intensity at intermediate discharge values.

The correspondence between the four classes of chlorophyll- $a$ identified above 489 (Fig. 7) and taxonomic composition of each cluster (Fig. 4) were determined by 490 allocating samples to the combination of discharge and light conditions under which they 491 were collected (Table 5). Total biomass increased five-fold, whereas chlorophyll- $a$ rose 492 eight-fold between the lowest and highest groups of plankton abundance. Centric diatoms 493 (Cluster I) always represented a high proportion of total biomass ( $\geq 40 \%)$, but accounted 494 for the highest fraction $(65 \%)$ of total biomass at intermediate discharges $\left(15-43 \mathrm{~m}^{3} \mathrm{~s}^{-1}\right)$. 495 Under both extreme high and extreme low discharge conditions, a mixed group of benthic 496 diatoms, chlorophytes, chrysophytes and pyrrhophytes (Clusters II and IV) dominated the 
497 biomass of plankton assemblages, and were complemented by truly planktonic centric 498 diatoms (Cluster I). Under the highest $\left(\geq 44 \mathrm{~m}^{3} \mathrm{~s}^{-1}\right)$ and lowest $(<15)$ discharge 499 conditions, mixed algae representing five phyta (Cluster II) were dominant (42-45\% of 500 total biomass). Cyanobacteria (Cluster III) always represented a minor fraction of total 501 biomass $(<3 \%)$, but they reached their highest biomass at intermediate discharge and 502 high illumination. Finally, sporadically occurring flagellates (Cluster IV) were most 503 common (15\%) under extreme high and extreme low discharge (Table 5).

\section{Discussion}

\section{Magnitude of phytoplankton blooms}

Results from the present study supported our first hypothesis that discharge and meteorological conditions determined the onset and magnitude of phytoplanktonic blooms in the nutrient-rich Rivière Yamaska. Over the 2008-2013 period, plankton

509 biomass was strongly correlated to discharge $(-)$ and indirectly linked to PAR $(+)$ and 510 precipitation (-), but showed little relationship to nutrient and DOC concentrations. These 511 results indicate that under conditions of excess nutrient concentrations, physical 512 conditions such as discharge and light availability control planktonic-bloom formation at 513 short (weekly), intermediate (seasonal) and long (inter-annual) time scales.

515 flashiness (ratio of maximum to minimum daily flow), which was reported to be high in 516 the Yamaska (842-fold), and the neighbouring Saint-François (181-fold) and

517 L'Assomption (134-fold) rivers (Hudon and Carignan 2008). Weather conditions and 518 discharge were primary drivers of phytoplankton community in temperate Rideau River 519 (Ontario) (Hamilton et al. 2012) as well as in tropical St. Johns River (Florida, U.S.A.) 
520 (Phlips et al. 2007). Light availability limited phytoplankton abundance in blackwater

521 lowland rivers such as the Rio Negro (Brazil) (Hammer 1965), the Rideau (Canada)

522 (Hamilton et al. 2012) and the St. Johns (U.S.A.) (Phlips et al. 2000).

523 Bursts of high discharge yielded the lowest Chl- $a$ concentrations. Maximum

524 chlorophyll- $a$ concentrations were forecasted to occur after three consecutive days of

525 intermediate $\left(15-43 \mathrm{~m}^{3} \mathrm{~s}^{-1}\right)$ discharge conditions and high light intensity. Surprisingly,

526 prolonged episodes of extreme drought $\left(<15 \mathrm{~m}^{3} \mathrm{~s}^{-1}\right)$ did not lead to major bloom events,

527 but rather to sustained high values of chlorophyll- $a$ and cell biomass. High

528 phytoplankton biomass $\left(120 \mu \mathrm{g}\right.$ Chl- $\left.a \mathrm{~L}^{-1}\right)$ was reported under low discharge $\left(<30 \mathrm{~m}^{3} \mathrm{~s}^{-1}\right)$

529 in large eutrophic rivers such as the Danube (Europe) (Kiss et al. 1994). Water discharge

530 and turbidity were shown to control phytoplankton abundance in numerous lowland

531 rivers such as the Someş (Romania/Hungary) (Istvánovics et al. 2014), the Po (Italy)

532 (Tavernini et al. 2011), the Adige (Italy) (Salmaso and Braioni 2008), the Ebro (Spain)

533 (Sabater et al. 2008), the Meuse (Belgium) (Descy et al. 1987), the Mississippi (U.S.A.)

534 (Baker and Baker 1979) and the Murray (Australia) (Hötzel and Croome 1996). Although

535 discharge is the most commonly used variables to describe residence time, water velocity

536 (a function of channel cross-section) is a more useful variable to compare the potential

537 for thermal stratification favourable to cyanobacterial development (Mitrovic et al. 2003).

538 In the free-flowing lower Rivière Yamaska, minimal current velocity $\left(0.08 \mathrm{~m} \mathrm{~s}^{-1}\right)$ under

539 drought conditions were still above values impeding cyanobacterial blooms $(0.03-0.05 \mathrm{~m}$

$540 \mathrm{~s}^{-1}$, Mitrovic et al. 2011). 


\section{Composition of phytoplankton blooms}

The phytoplankton species in the lower Rivière Yamaska were typical of

544 assemblages occurring in many temperate, nutrient-rich riverine systems around the

545 world. Centric diatom assemblages found in our study are similar to the flora of the Loire

546 (France) (Abonyi et al. 2012), the Tisza (Europe) (Istvánovics et al. 2010) and the

547 Danube (Várbíró et al. 2007), which were characterized by Scenedesmus spp., Cyclotella

548 meneghiniana, Nitzschia acicularis, Skeletonema potamos and Stephanodiscus hantzschii.

549 In the Rivière Yamaska, centric diatoms dominated over most summers, except for the

550 dry summer of 2013, which had higher abundances of chlorophytes (e.g., Pteromonas

551 aculeata, Chlamydomonas spp.) and cryptophytes (e.g., Cryptomonas erosa). The

552 tolerance of centric diatoms and mixotrophic cryptomonads to low light availability is

553 well documented (Reynolds and Descy 1996) and explains their year-round dominance in

554 large rivers (Rojo et al. 1994; Hudon 2000; Hamilton et al. 2011; Abonyi et al. 2012). It

555 is noteworthy that summers of lowest discharge in the Yamaska $(2012,2013)$ coincided

556 with a reduction in diatom abundance. Diatoms were replaced by small, motile, flagellate

557 taxa better suited to withstand low turbulence and maintain themselves in the water

558 column (Kruk et al. 2010; Istvánovics et al. 2010).

559 Although riverine plankton assemblages tend to be dominated by truly planktonic

560 species, benthic and tychoplanktonic taxa (e.g., Ulnaria spp., Fragilaria spp.) detached

561 from their substrate or brought in by tributaries and from slow-flowing littoral areas also

562 contribute to seston diversity (Hudon et al. 1996). The group of taxa defined by our

563 Cluster II included many tychoplanktonic taxa (euglenoids, pennate diatoms,

564 pyrrhophytes, cryptophytes, various chlorophytes), which together represented $25-45 \%$ 
565 of total plankton biomass, depending on the combination of discharge and incident light 566 intensity.

567 Local production vs. advection of plankton from upstream reservoirs

Our short-term measurements of $\mathrm{O}_{2}$ production under rising and falling discharge

569 (2008) revealed that plankton production was temporarily interrupted during episodes of

570 rising discharge, but resumed when discharge returned to low values. In contrast, during

571 the dry summer of 2012, planktonic $\mathrm{O}_{2}$ production and biomass remained generally high,

572 but were modulated by climatic events (sunshine, precipitation).

573 In upstream lakes and reservoirs, eutrophic conditions and longer residence times

574 favoured toxic cyanobacterial blooms. Public reports of cyanobacterial occurrence likely

575 underestimate the frequency and duration of cyanobacterial blooms. Public reports to

576 MDDELCC suggested that such episodes occurred independently within each

577 impoundment and did not show evidence of spreading downstream. Indeed, in the 1000

578 km-long Loire (Abonyi et al. 2012) and the Murray River (Al-Tebrineh et al. 2012),

579 markedly different planktonic assemblages were shown to occur simultaneously in

580 spatially distant reaches representing different riverine habitats. During the summer 2010

581 drought event in Australia, however, a bloom of Dolichospermum (Anabaena) circinalis

582 confined to a small package of water was followed over a distance of $650 \mathrm{~km}$ in the mid-

583 and lower Murray River (Bowling et al. 2013). Targeted surveys should be carried out in

584 the future to determine the fate of blooms in Yamaska reservoirs once they are released

585 downstream. 
Persistent turbulence, dilution by incoming tributaries and short residence time

587 could limit cyanobacterial abundance in the free-flowing downstream reach of the Rivière

588 Yamaska, even under the lowest discharge conditions observed in this study. Lake

589 Ontario plankton showed a clear shift in composition and biomass after entrainment into

590 turbulent St. Lawrence River (Hudon et al. 1996). Cyanobacterial assemblages growing

591 in the upper reaches of the Rivière Yamaska do not persist after being flushed out of

592 stratified reservoirs into the free-flowing, turbid river stem, regardless of discharge

593 condition. Under high discharge conditions, transit time is short, but underwater light is

594 restricted by deep waters whereas under low discharge conditions, transit time is long, but

595 underwater light conditions are more favourable. As shown by our measurements of

596 short-term $\mathrm{O}_{2}$ production, bloom formation in the lower reaches of the river were rather

597 controlled by enhanced local plankton production under intermediate discharge and

598 sunny conditions.

599 Why aren't lower Rivière Yamaska blooms dominated by cyanobacteria?

600 Contrary to our second hypothesis, the lowest discharge did not lead to the dominance of

601 cyanobacteria blooms in the lower Rivière Yamaska, as previously reported for eutrophic

602 rivers experiencing drought conditions (e.g., Nakdong River (South Korea), Jeong et al.

603 2007; Murray River (Australia), Bowling et al. 2013). Under low discharge conditions in

604 the Rivière Yamaska (2012), water temperature was warmer (by about $3^{\circ} \mathrm{C}$ ), the river

605 was shallower (by about $2 \mathrm{~m}$ ) and the water column was better illuminated (Zeu /Zt $\approx 0.9$

606 instead of $\approx 0.3$ ) than under high discharge (2008) conditions. Although current speed

607 was markedly reduced $\left(<0.1 \mathrm{~m} \mathrm{~s}^{-1}\right)$ under low discharge conditions, river flow remained

608 turbulent, as shown by high values of Reynolds number. Under high turbulence and 
nutrient availability, slow-growing cyanobacteria cannot compete with fast-growing

610 diatoms and chlorophytes (Reynolds and Descy 1996). The presence of slow-flowing

611 reaches, fluvial lakes and impoundments along the course of the river likely plays a major

612 role in cyanobacterial proliferation. In the temperate Spree (Europe) (Köhler 1993) as

613 well as in tropical Darling River (Hötzel and Croome 1994; Mitrovic et al. 2003) and St.

614 Johns River (Phlips et al. 2007), prolonged retention time of water in fluvial

615 lakes/impoundments were shown to allow the development of stable cyanobacteria

616 populations. Under calm conditions, planktonic diatoms are replaced by flagellated taxa,

617 which are eventually outcompeted by cyanobacteria that can control their depth in

618 stratified systems.

619 Management implications

620 Given the forecasted changes in climate for southern Quebec (CEHQ 2015),

621 prolonged drought periods followed by episodes of heavy rainfall and warmer

622 temperatures are likely to occur more frequently during summer. Such conditions will

623 exacerbate the problem of eutrophication, particularly the proliferation of potentially

624 toxic cyanobacteria (Paerl et al. 2011). Chronically low discharge could intensify the

625 pressure to construct additional dams and water retention structures along the course of

626 the Rivière Yamaska, thus increasing residence time and particle sedimentation, and

627 favouring vertical stratification in the river. In turn, the development of a stable

628 epilimnetic layer with high light availability will likely enhance the development of

629 blooms of potentially toxic, diazotrophic cyanobacteria. For example, in nutrient-rich,

630 heavily impounded river systems such as the Murray and Nakdong rivers, cyanobacterial

631 blooms were mitigated through discharge management (Jeong et al. 2007; Mitrovic et al. 
632

\section{3}

634

635

2003, 2011). Cyanobacterial blooms are a common occurrence in the upper Rivière

Yamaska and our study highlighted the strong interaction between river discharge and

bloom magnitude and species composition. Although the flow in the lower reaches of

Rivière Yamaska has so far remained sufficient to avoid cyanobacterial proliferation, our

results suggest that further increasing water residence time, either through severe drought

or river damming, will amplify the risk of toxic algal blooms.

\section{Acknowledgements}

We thank Jean-Pierre Amyot, Michel Arseneau and Conrad Beauvais for their help with field work, sample collection and automated probe moorings. Eric Valiquette, manager of the Station de Biologie des Laurentides at Saint-Hippolyte (Université de Montréal), shared PAR data. Characterization of the Rivière Yamaska flow regime was made possible by the information supplied by Luc Gauthier (MDDELCC). We thank Nathalie Bourbonnais (MDDELCC) for providing information on cyanobacteria in the Yamaska watershed and Sylvie Blais (MDDELCC) for commenting on an earlier version of the manuscript. The staff of the ECCC-Centre Saint-Laurent laboratory (LEEQ) carried out water-quality analyses. François Boudreault provided information on land use and drew the location map. Figures were drafted by Maude Lachapelle. This study was funded by the St. Lawrence Action Plan (SLAP) and Environment and Climate Change Canada (ECCC).

\section{References}

Abonyi, A., Leitão, M., Lançon, A.M., and Padisák, J. 2012. Phytoplankton functional groups as indicators of human impacts along the River Loire (France). Hydrobiologia, 698: 233-249. doi:10.1007/s10750-012-1130-0

Al-Tebrineh, J., Merrick, C., Humpage, A., Bowling, L. and Neilan, B.A. 2012. Community composition, toxigenicity and environmental conditions during a cyanobacterial bloom occurring along 1,100 kilometers of the Murray River. Appl. Environm. Microbiol. 78, 263-272. doi:10.1128/AEM.05587-11

Baker, A.L., and Baker, K.K. 1979. Effects of temperature and current discharge on the concentration and photosynthetic activity of the phytoplankton in the upper Mississippi River. Freshw. Biol., 9: 191-198. doi:10.1111/j.13652427.1979.tb01502.x 
Bowling, L.C., Merrick, C., Swann, J., Green, D., Smith G. and Neilan, B.A. 2013. Effects of hydrology and river management on the distribution, abundance and persistence of cyanobacterial blooms in the Murray River, Australia. Harmful Algae 30, 27-36. http://dx.doi.org/10.1016/j.hal.2013.08.002

CEHQ (Centre d'expertise hydrique du Québec). 2014. Daily discharge of Rivière Yamaska $1.8 \mathrm{~km}$ downstream of the Saint-Hyacinthe dam (station 030345), downloaded from: https://www.cehq.gouv.qc.ca/hydrometrie/historique donnees/fiche station.asp?No $\underline{\text { Station }=030345}$ Consultation in December 2014.

CEHQ (Centre d'expertise hydrique du Québec). 2015. Atlas hydroclimatique du Québec méridional - Impact des changements climatiques sur les régimes de crue, d'étiage et d'hydraulicité à l'horizon 2050. Québec.

CEHQ (Centre d'expertise hydrique du Québec). 2016. Reservoir information from https://www.cehq.gouv.qc.ca/barrages/ListeBarrages.asp?region=Mont\%E9r\%E9gi e\&Num $=16 \&$ Tri $=$ No\&contenance $1=0$ on $\&$ contenance $2=$ on $\&$ contenance $3=$ on; Consultation in September 2016.

Compère, P. 1989. Flore pratique des algues d'eau douce de Belgique. 2. Pyrrhophytes (Cryptophyceae, Dinophyceae), raphidophytes (Raphidiophyceae), euglénophytes (Euglenophyceae). Jardin Botanique National de Belgique, Meise, Belgium.

Conley, D.J., Paerl, H.W., Howarth, R.W., Boesch, D.F., Seitzinger, S.P., Karl, E., Karl, E., Lancelot, C., Gene, E., and Gene, E. 2009. Controlling eutrophication: nitrogen and phosphorus. Science, 123: 1014-1015. doi:10.1126/science.1167755

De'ath, G., and Fabricius, K.E. 2000. Classification and regression trees: a powerful yet simple technique for ecological data analysis. Ecology, 81: 3178-3192. doi: 10.1890/0012-9658(2000)081[3178:CARTAP]2.0.CO;2

Deblois, C.P., Mochon, A., and Juneau, P. 2008. Toxines de cyanobactéries dans les perchaudes: Analyse exploratoire dans quatre lacs du bassin de la rivière Yamaska. Le Naturaliste Canadien, 132: 56-59.

Descy, J.P., Servais, P., Smitz, J.S., Billen, G., and Everbecq, E. 1987. Phytoplankton biomass and production in the River Meuse (Belgium). Water Res., 21: 1557-1566. doi:10.1016/0043-1354(87)90141-2 
Environment Canada. 2005. Manuel des méthodes d'analyses (annexe B). Environment Canada, Quebec Region, Scientific and Technical Services Section. St. Lawrence Centre, Montréal, Quebec, Canada.

Ettl, H., and Gärtner, G. 1988. Chlorophyta. II. Tetrasporales, Chlorococcales, Gleodendrales. In Sübwasserflora von Mitteleuropa. Edited by H. Ettl, J. Gerloff, H. Heynig, and D. Mollenhauer. Gustav Fisher Verlag, Stuttgart.

Findlay, D.L., and Kling, H.J. 1979. A species list and pictorial reference to the phytoplankton of Central and Northern Canada - Parts I and II. Fish. Mar. Serv. Manuscr. Rep. 1503. Department of Fisheries and the Environment, Western Region, Fisheries and Marine Service, Winnipeg, Man.

Germain, H. 1981. Flore des diatomées, diatomophycées. Eaux douces et saumâtres du Massif Armoricain et des contrées voisines d'Europe occidentale. Société Nouvelle des Éditions Boubée, Paris.

Gosselain, V., and Hamilton, P.B. 2000. Algamica: revisions to a key-based computerized counting program for free-living, attached and benthic algae. Hydrobiologia, 438: 138-142. doi:10.1023/A:1004122331683

Hamilton, P.B., Ley, L.M., Poulin, M., and Pick, F.R. 1997. Seasonal and disturbance event fluctuations in phytoplankton composition and water quality in the lower Rideau River, including Mooney's Bay, during 1996. Parts 1-3. Centre for Aquatic Biology and Environmental Research (CABER) Technical Report, Canadian Museum of Nature 97/1-3, Ottawa, Ont.

Hamilton, P.B. Proulx, M., and Earle, C. 2002. Enumerating phytoplankton with an upright compound microscope using a modified settling chamber. Hydrobiologia, 444: 171-175. doi:10.1023/A:1017523301767

Hamilton, P.B., Lavoie, I., Ley, L.M., and Poulin, M. 2011. Factors contributing to the spatial and temporal variability of phytoplankton communities in the Rideau River (Ontario, Canada). River Syst., 19: 189-205. doi:10.1127/1868-5749/2011/0190026

Hamilton, P.B., Lavoie, I., and Poulin, M., 2012. Spatial, seasonal and inter-annual variability in environmental characteristics and phytoplankton standing stock of the 
temperate, lowland Rideau River, Ontario, Canada. River Research and Applications, 28: 1551-1566. doi:10.1002/rra.1543

Hammer, L. 1965. Photosynthese und Primärproduktion im Rio Negro. Int. Rev. Gesamten Hydrobiol. Hydrogr., 50: 335-339. doi:10.1002/iroh.19650500303

Hecky, R.E., and Kilham, P. 1988. Nutrient limitation of phytoplankton in freshwater and marine environments: A review of recent evidence on the effects of enrichment. Limnol. Oceanogr., 33: 796-822. doi:10.4319/lo.1988.33.4part2.0796

Hillebrand, H., Dursselen, C.D., Kirschel, D., Pollingher, U., and Zohary, T. 1999. Biovolume calculation for pelagic and benthic microalgae. Journal of Phycology, 35: 403-425. doi:10.1046/j.1529-8817.1999.3520403.x

Hoekstra, A.Y., Chapagain, A.K., Aldaya, M.M., and Mekonnen, M.M. 2011. The water footprint assessment manual, setting the global standard, (Earthscan London, TJ International Ltd, Cornwall). ISBN: 978-1-84971-279-8.

Hötzel, G., and Croome, R. 1994. Long-term phytoplankton monitoring of the Darling River at Burtundy, New South Wales: Incidence and significance of cyanobacterial blooms Australian Journal of Marine and Freshwater Research 45: 747-759 http://dx.doi.org/10.1071/MF9940747

Hötzel, G., and Croome, R. 1996. Population dynamics of Aulacoseira granulata (Ehr.) Simonson (Bacillariophyceae, Centrales), the dominant alga in the Murray River, Australia. Archiv für Hydrobiologie, 136: 191-215. ISSN:0003-9136

Hüber-Pestalozzi, G. 1938. Das phytoplankton des Sübwassers Systematik und Biologie. Teil 1. Blaualgen. Bakterien. Pilze. In Die Binnengewässer. Band 16. Edited by H.J. Elster and W. Ohle. Stuttgart.

Hüber-Pestalozzi, G. 1961. Das phytoplankton des Sübwassers Systematik und Biologie. Teil 5. Chlorophyceae (Grünalgen) Ordnung: Volvocales. In Die Binnengewässer. Band 16. Edited by H.J. Elster and W. Ohle. Stuttgart.

Hüber-Pestalozzi, G. 1968. Das phytoplankton des Sübwassers Systematik und Biologie. Teil 3. Cryptophyceae, Chloromonadophyceae, Dinophyceae. In Die Binnengewässer. Band 16. Edited by H.J. Elster and W. Ohle. Stuttgart. 
753 754

755

756

Hudon, C., Paquet, S., and Jarry, V. 1996. Downstream variations of phytoplankton in the St. Lawrence River (Québec, Canada). Hydrobiologia, 337 : 11-26. doi:10.1007/BF00028503

Hudon, C. 2000. Phytoplankton assemblages in the St. Lawrence River, downstream of its confluence with the Ottawa River, Quebec, Canada. Can. J. Fish. Aquat. Sci. 57: 16-30. doi:10.1139/f99-228

Hudon, C., and Carignan, R. 2008. Cumulative impacts of hydrology and human activities on water quality in the St. Lawrence River (Lake Saint-Pierre, Quebec, Canada). Can. J. Fish. Aquat. Sci., 65: 1165-1180. doi:10.1139/F08-069

Istvánovics, V., Honti, M., Vörös, L., and Kozma, Z. 2010. Phytoplankton dynamics in relation to connectivity, flow dynamics and resource availability - the case of a large, lowland river, the Hungarian Tisza. Hydrobiologia, 637: 121-141. doi: 10.1007/s10750-009-9991-6

INSPQ Institut National de Santé Publique du Québec 2005. Propositions de critères d'intervention et de seuils d'alerte pour les cyanobactéries, $4 \mathrm{p}$. https://www.inspq.qc.ca/pdf/publications/348-Criteres/nterventionCyanobacteries.pdf

Istvánovics, V., and Honti, M. 2011. Phytoplankton growth in three rivers: The role of meroplankton and the benthic retention hypothesis. Limnology and Oceanography, 56: 1439-1452. doi:10.4319/1o.2011.56.4.1439.

Istvánovics, V., Honti, M., Kovács, Á., Kocsis, G., and Stier, I. 2014. Phytoplankton growth in relation to network topology: time-averaged catchment-scale modelling in a large lowland river. Freshwater Biology, 59: 1856-1871. doi: $10.1111 /$ fwb. 12388

Jeong, K.-S., Kimb, D.-K., and Joo, G.-J. 2007. Delayed influence of dam storage and discharge on the determination of seasonal proliferations of Microcystis aeruginosa and Stephanodiscus hantzschii in a regulated river system of the lower Nakdong River (South Korea). Water Research, 41:1269-1279. doi:10.1016/J.watres.2006.11.054

Kiss, K.T., Ács, É., and Kovács, A. 1994. Ecological observations on Skeletonema potamos (Weber) Hasle in the River Danube, near Budapest (1991-92, daily investigations). Hydrobiologia, 289: 163-170. doi:10.1007/BF00007417 
Köhler, J. 1993. Growth, production and losses of phytoplankton in the lowland River Spree. 1. Population dynamics. J. Plankton Res. 15: 335-349. doi:10.1093/plankt/15.3.335

Krammer, K., and Lange-Bertalot, H. 1986-1991. Bacillariophyceae. In Sübwasserflora von Mitteleuropa. Band 2 (1-4). Edited by H. Ettl, J. Gerloff, H. Heinig, and D. Mollenhauer. Gustav Fisher Verlag, Stuttgart, Jena.

Kruk, C., Huszar, V.L., Peeters, E.T., Bonilla, S., Costa, L., Lürling, M., Reynolds, C.S., and Scheffer, M. 2010. A morphological classification capturing functional variation in phytoplankton. Freshw. Biol., 55: 614-627. doi:10.1111/j.13652427.2009.02298.x

Lorenzen, C.J. 1967. Determination of chlorophyll and pheo-pigments: Spectrophotometric equations. Limnol. Oceanogr., 12: 343-346. doi:10.4319/1o.1967.12.2.0343

MDDEFP (Ministère du Développement durable, de l'Environnement, de la Faune et des Parcs). 2014. Bilan de la gestion des épisodes de fleurs d'eau d'algues bleu-vert, de 2007 à 2012, Québec, Direction du suivi de l'état de l'environnement. ISBN 978-2550-70347-1 (PDF), $32 \mathrm{p}$.

MDDELCC (Ministère du Développement durable, de l'Environnement et de la Lutte contre les changements climatiques) 2016. Banque de données du Plan de gestion des épisodes de fleurs d'eau d'algues bleu-vert. Direction générale du suivi de l'état de l'environnement, Québec, Septembre 2016.

Mitrovic, S.M., Oliver, R.L., Rees, C., Bowling, L.C., and Buckney, R.T. 2003. Critical flow velocities for the growth and dominance of Anabaena circinalis in some turbid freshwater rivers. Freshw. Biol., 48: 164-174.

Mitrovic, S.M., Hardwick, L., and Dorani, F. 2011. Use of flow management to mitigate cyanobacterial blooms in the Lower Darling River, Australia. J. Plankt. Res. 33, 229-241.

Paerl, H.W., Hall, N.S., and Calandrino, E.S. 2011. Controlling harmful cyanobacterial blooms in a world experiencing anthropogenic and climatic-induced change. Sci. Total Environ., 409: 1739-1745. doi:10.1016/j.scitotenv.2011.02.001 
Phlips, E.J., Cichra, M., Aldridge, F.J., Jembeck, J., Hendrickson, J., and Brody, R. 2000. Light availability and variations in phytoplankton standing crops in a nutrient-rich blackwater river. Limnol. Oceanogr., 45: 916-929. doi:10.4319/lo.2000.45.4.0916

Phlips, E.J., Hendrickson, J., Quinlan, E.L., and Cichra, M. 2007. Meteorological influences on algal bloom potential in a nutrient-rich blackwater river. Freshw. Biol., 52: 2141-2155. doi:10.1111/j.1365-2427.2007.01844.x

Pick, F.R. 2016. Blooming algae: a Canadian perspective on the rise of toxic cyanobacteria. Can. J. Fish. Aquat. Sci. 73: 1-10. doi:10.1139/cjfas-2015-0470

Prescott, G.W. 1951. Algae of the western Great Lakes area. Otto Koeltz Science Publishers, Koenigstein.

Gouvernement du Québec 2016. Regulation respecting the quality of drinking water. Chapter Q-2, r. 40, updated November 1st 2016. [Québec], Éditeur officiel du Québec. (http://legisquebec.gouv.qc.ca/en/ShowDoc/cr/Q-2,\%20r.\%2040)

Reynolds, C.S., and Descy, J.-P. 1996. The production, biomass and structure of phytoplankton in large rivers. Archiv für Hydrobiol., 10: 161-187 (Supplement Large Rivers). doi:10.1127/lr/10/1996/161

Rojo C., Alvarez Cobelas, M., and Arauzo, M. 1994. An elementary, structural analysis of river phytoplankton. In Phytoplankton in Turbid Environments: Rivers and Shallow Lakes. Edited by J.-P. Descy, C. S. Reynolds \& J. Padisdk. Hydrobiologia, 289: $43-55$.

Rolland, A., Bird, D.F., and Giani, A. 2005. Seasonal changes in composition of the cyanobacterial community and the occurrence of hepatotoxic blooms in the eastern townships, Québec, Canada. J. Plankton Res., 27: 683-694. doi:10.1093/plankt/fbi042

Sabater, S., Artigas, J., Durán, C., Pardos, M., Romaní, A.M., Tornés, E., and Ylla, I. 2008. Longitudinal development of chlorophyll and phytoplankton assemblages in a regulated large river (the Ebro River). Science of the total environment, 404: 196206. doi: 10.1016/j.scitotenv.2008.06.013

Salmaso, N., and Braioni, M.G. 2008. Factors controlling the seasonal development and distribution of the phytoplankton community in the lowland course of a large river 
in Northern Italy (River Adige). Aquat. Ecol., 42: 533-545. doi:10.1007/s10452007-9135-X

846 Søballe, D.M., and Kimmel, B.L. 1987. A large-scale comparison of factors influencing phytoplankton in rivers, lakes, and impoundment. Ecology, 68: 1943-1954. doi:10.2307/1939885

849 Statistics Canada. 2011. Population census 2011 data by dissemination blocks.

850 Tavernini, S., Pierobon, E., and Viaroli, P. 2011. Physical factors and dissolved reactive 851 silica affect phytoplankton community structure and dynamics in a lowland

Wetzel, R.G., and Likens, G.E. 1991. Limnological analyses. $2^{\text {nd }}$ edition. SpringerVerlag, New-York. ISBN:978-1-4757-3250-4 
Table 1. Hydrological characteristics of Rivière Yamaska (north branch) at five gauging stations located downstream of an impoundment, derived from point measurements obtained at individual river cross-sections under low and high discharge conditions. Reservoir information from CEHQ (2016). Hydrometric information at gauging stations from Luc Gauthier, MDDELCC (personal communication). Information on reported cyanobacterial occurrences (MDDELCC 2016).

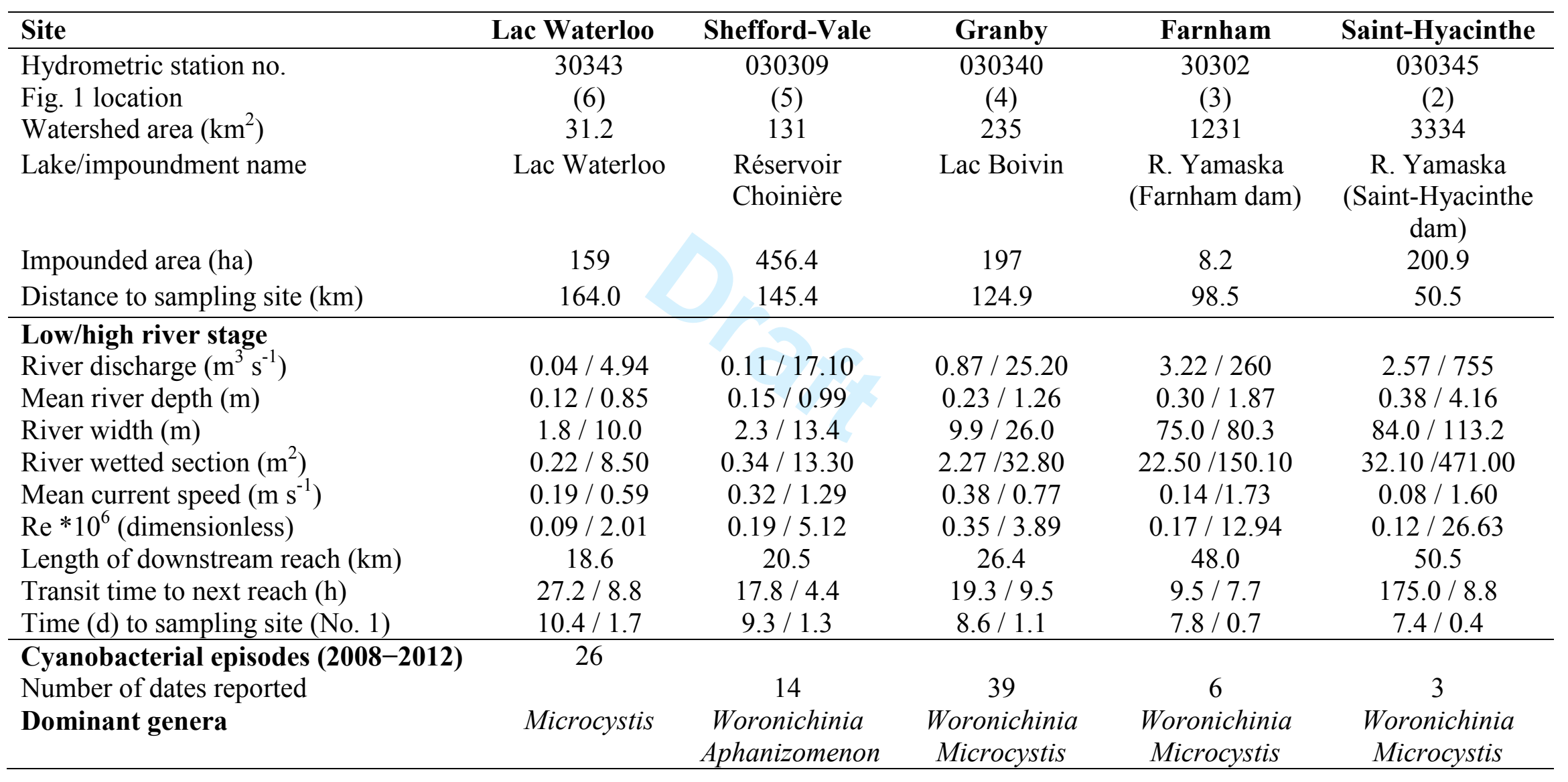


870

\begin{tabular}{|c|c|c|c|c|c|c|c|}
\hline & 2008 & 2009 & 2010 & 2011 & 2012 & 2013 & $\begin{array}{c}\text { ANOVA } \\
\text { (signif) }\end{array}$ \\
\hline Sampling period & $\begin{array}{l}\text { Jun. } 25- \\
\text { Sept. } 24\end{array}$ & $\begin{array}{c}\text { Jun. } 29- \\
\text { Sept. } 9\end{array}$ & $\begin{array}{c}\text { July } 13- \\
\text { Sept. } 29\end{array}$ & $\begin{array}{c}\text { May } 31- \\
\text { Aug. } 24\end{array}$ & $\begin{array}{c}\text { June } 26- \\
\text { Sept. } 17\end{array}$ & $\begin{array}{l}\text { July } 2- \\
\text { Aug. } 27\end{array}$ & Years \\
\hline $\begin{array}{l}\text { Discharge } \\
\left(\mathrm{Q}, \mathrm{m}^{3} \mathrm{~s}^{-1}\right)\end{array}$ & $\begin{array}{c}63.6 a \\
(96.0,91)\end{array}$ & $\begin{array}{c}47.7 a b \\
(50.9,67)\end{array}$ & $\begin{array}{c}24.9 b c \\
(26.0,72)\end{array}$ & $\begin{array}{c}22.4 c \\
(20.5,86)\end{array}$ & $\begin{array}{c}8.0 c \\
(6.3,83)\end{array}$ & $\begin{array}{c}14.2 c \\
(8.5,50)\end{array}$ & $* * *$ \\
\hline $\begin{array}{l}\text { Photosynthetically } \\
\text { active radiation } \\
\left(\mu \mathrm{mol} \mathrm{m} \mathrm{m}^{-2} \mathrm{~s}^{-1}\right)\end{array}$ & $\begin{array}{c}601.2 b \\
(222.1,83)\end{array}$ & $\begin{array}{l}583.8 b \\
(223.4 \\
73)\end{array}$ & $\begin{array}{l}586.4 b \\
(250.2 \\
79)\end{array}$ & $\begin{array}{c}753.9 a \\
(255.4 \\
86)\end{array}$ & $\begin{array}{c}772.3 a \\
(242.1 \\
84)\end{array}$ & $\begin{array}{c}801.2 a \\
(227.4 \\
54)\end{array}$ & $* * *$ \\
\hline Precipitation (mm) & $\begin{array}{c}4.4 a \\
(10.4,91)\end{array}$ & $\begin{array}{c}3.0 a \\
(8.2,67)\end{array}$ & $\begin{array}{c}3.3 a \\
(6.6,72)\end{array}$ & $\begin{array}{c}2.3 a \\
(5.1,58)\end{array}$ & $\begin{array}{c}2.4 a \\
(5.8,83)\end{array}$ & $\begin{array}{c}2.4 a \\
(5.4,50)\end{array}$ & n.s. \\
\hline
\end{tabular}
and precipitation recorded over the period of water quality and phytoplankton sampling of each year $(\mathrm{N}=$ number of days). different (n.s.: not significant; $\mathrm{p}<0.001$ : highly significant difference $* * *$; n.a.: not available).

Table 2. Mean (s.d., N) Rivière Yamaska discharge (at Saint-Hyacinthe, CEHQ station 030345), photosynthetically active radiation

Differences among years were tested using one-way ANOVA (of Log-transformed values); letters indicate years that are significantly 
Table 3. Mean (s.d., N) daily values of water temperature and turbidity and concentrations of chemicals measured at the time of phytoplankton sample collection at our sampling site (Fig. 1, No. 1) in the Rivière Yamaska (2008-2013). Water temperature and turbidity data were obtained from the high frequency YSI multi-probe mooring for the entire sampling period. Because the YSI mooring covered a shorter period in 2012 (June 26 - July 28) than in 2008, 2009 and 2011, it was excluded from the inter-annual comparisons of temperature and turbidity. Results presented are for a one-way ANOVA (Log-transformed values) between years; letters indicate years that are significantly different (n.s.: not significant; $\mathrm{p}<0.001$ : highly significant difference $* * *$; n.a.: not available).

\begin{tabular}{|c|c|c|c|c|c|c|c|}
\hline & 2008 & 2009 & 2010 & 2011 & 2012 & 2013 & $\begin{array}{c}\text { ANOVA } \\
\text { (signif) }\end{array}$ \\
\hline $\begin{array}{l}\text { Water } \\
\text { temperature }\left({ }^{\circ} \mathrm{C}\right)\end{array}$ & $\begin{array}{c}21.8 a \\
(2.5,92)\end{array}$ & $\begin{array}{l}22.2 a b \\
(2.1,73)\end{array}$ & n.a. & $\begin{array}{c}23.3 b \\
(2.4,77)\end{array}$ & $\begin{array}{c}25.0 \\
(1.7,44)\end{array}$ & n.a. & $* * *$ \\
\hline Turbidity (NTU) & $\begin{array}{c}45.8 a \\
(45.5,92)\end{array}$ & $\begin{array}{c}108.1 b \\
(76.8,70)\end{array}$ & n.a. & $\begin{array}{c}94.7 b \\
(29.6,72)\end{array}$ & $\begin{array}{c}268.2 \\
(278.0,37)\end{array}$ & n.a. & $* * *$ \\
\hline $\mathrm{k}\left(\mathrm{m}^{-1}\right)$ & $\begin{array}{c}4.55 a \\
(0.70,13)\end{array}$ & $\begin{array}{l}5.20 a b \\
(1.81,7)\end{array}$ & $\begin{array}{c}6.61 b \\
(0.35,8)\end{array}$ & $\begin{array}{c}5.14 a b \\
(1.72,11)\end{array}$ & $\begin{array}{l}5.39 a b \\
(1.12,7)\end{array}$ & $\begin{array}{l}5.25 a b \\
(0.86,9)\end{array}$ & $* * *$ \\
\hline $\begin{array}{l}\text { Suspended } \\
\text { particulate matter } \\
\left(\mathrm{mg} \mathrm{L}^{-1}\right)\end{array}$ & $\begin{array}{c}27.5 b \\
(7.9,14)\end{array}$ & $\begin{array}{l}44.4 a b \\
(25.5,7)\end{array}$ & $\begin{array}{c}78.6 a \\
(11.0,10)\end{array}$ & $\begin{array}{c}61.7 a b \\
(37.6,11)\end{array}$ & $\begin{array}{c}78.1 a \\
(33.8,7)\end{array}$ & $\begin{array}{l}56.1 a b \\
(20.6,9)\end{array}$ & $* * *$ \\
\hline $\begin{array}{l}\text { DOC } \\
\left(\mathrm{mg} \mathrm{C} \mathrm{L}^{-1}\right)\end{array}$ & $\begin{array}{c}8.3 a \\
(1.3,13)\end{array}$ & $\begin{array}{c}8.0 a \\
(0.4,7)\end{array}$ & $\begin{array}{l}7.5 a b \\
(0.6,8)\end{array}$ & $\begin{array}{c}6.2 c d \\
(0.7,11)\end{array}$ & $\begin{array}{c}5.4 d \\
(0.3,7)\end{array}$ & $\begin{array}{l}6.6 b c \\
(0.8,9)\end{array}$ & $* * *$ \\
\hline $\mathrm{TN}\left(\mathrm{mg} \mathrm{N} \mathrm{L}{ }^{-1}\right)$ & n.a. & $\begin{array}{c}3.0 a \\
(1.4,7)\end{array}$ & $\begin{array}{c}1.9 a \\
(0.6,8)\end{array}$ & $\begin{array}{c}2.6 a \\
(1.5,11)\end{array}$ & $\begin{array}{c}1.0 \mathrm{~b} \\
(0.3,7)\end{array}$ & $\begin{array}{c}2.1 a \\
(0.9,9)\end{array}$ & $* * *$ \\
\hline
\end{tabular}




$\begin{array}{lccccccc}\mathrm{NO}_{2}-\mathrm{NO}_{3} & 1.2 a b & 2.2 a b & 1.1 a b & 1.7 a & 0.4 b & 1.5 \mathrm{a} b & \text { n.s. } \\ \left(\mathrm{mg} \mathrm{N} \mathrm{L}^{-1}\right) & (0.5,14) & (1.5,7) & (0.7,9) & (1.6,11) & (0.2,4) & (1.1,9) & \\ & 21.0 a b & 29.1 a b & 15.1 a b & 36.0 a & 9.0 b & 15.8 \mathrm{a} b & \text { n.s. } \\ \mathrm{NH}_{4} & (12.2,12) & (24.1,7) & (4.3,8) & (39.4,11) & (3.9,7) & (7.2,9) & \\ \left(\mu \mathrm{g} \mathrm{N} \mathrm{L}^{-1}\right) & 106.5 a & 140.1 a & 140.9 a & 130.2 a & 141.9 a & 119.7 a & \text { n.s. } \\ \mathrm{TP} & (29.1,13) & (33.3,7) & (22.8,9) & (37.1,11) & (37.2,7) & (25.5,9) & \\ (\mu \mathrm{g} \mathrm{P} \mathrm{L} & & & & & & & \\ \mathrm{TDP} & 50.7 a & 57.0 a & 45.1 a & 41.0 a & 35.9 a & 35.3 a & \text { n.s. } \\ \left(\mu \mathrm{g} \mathrm{P} \mathrm{L} \mathrm{P}^{-1}\right) & (25.6,13) & (34.1,7) & (20.2,8) & (22.2,11) & (10.1,7) & (17.4,9) & \end{array}$


Table 4. Mean (s.d.) total biomass, chlorophyll- $a$ concentration and biomass of individual taxa representing at least $5 \%$ of total plankton biomass for each year at our sampling site (Fig. 1, No. 1) in the Rivière Yamaska (2008-2013). For each year, the number of samples (N) for taxonomical analysis is specified. Dominant taxa are indicated for each taxonomical group. The cluster to which each taxon is associated from Fig. 4 is shown. (Note: - : not recorded; x: taxa representing $<5 \%$ of average biomass).

\begin{tabular}{|c|c|c|c|c|c|c|c|}
\hline & $\begin{array}{c}2008 \\
(\mathrm{~N}=10)\end{array}$ & $\begin{array}{c}2009 \\
(\mathrm{~N}=10)\end{array}$ & $\begin{array}{c}2010 \\
(\mathrm{~N}=11)\end{array}$ & $\begin{array}{c}2011 \\
(\mathrm{~N}=12)\end{array}$ & $\begin{array}{c}2012 \\
(\mathrm{~N}=8)\end{array}$ & $\begin{array}{c}2013 \\
(\mathrm{~N}=9)\end{array}$ & $\begin{array}{l}\text { Cluster } \\
\text { (Fig. 4) }\end{array}$ \\
\hline $\begin{array}{l}\text { Cell biomass } \\
\left(\mu g \mathrm{~L}^{-1}\right)\end{array}$ & $\begin{array}{c}1930.9 \\
(2335.3)\end{array}$ & $\begin{array}{c}2518.0 \\
(2615.1)\end{array}$ & $\begin{array}{l}1078.7 \\
(653.0)\end{array}$ & $\begin{array}{c}2876.9 \\
(2626.5)\end{array}$ & $\begin{array}{l}1355.2 \\
(804.5)\end{array}$ & $\begin{array}{c}4071.2 \\
(4128.9)\end{array}$ & \\
\hline $\begin{array}{l}\text { Chlorophyll- } a \\
\left(\mu \mathrm{g} \mathrm{Chl-} a \mathrm{~L}^{-1}\right)\end{array}$ & $\begin{array}{c}24.2 \\
(23.0)\end{array}$ & $\begin{array}{l}27.0 \\
(25.0)\end{array}$ & $\begin{array}{l}25.3 \\
(9.7)\end{array}$ & $\begin{array}{c}25.8 \\
(18.6)\end{array}$ & $\begin{array}{l}25.1 \\
(7.7)\end{array}$ & $\begin{array}{c}28.6 \\
(18.3)\end{array}$ & \\
\hline \multicolumn{8}{|l|}{ Diatoms } \\
\hline $\begin{array}{l}\text { Aulacoseira granulata (Ehrenb.) } \\
\text { Sim. }\end{array}$ & $\mathrm{x}$ & $\mathrm{x}$ & $\mathrm{x}$ & 137.5 & $\mathrm{x}$ & $\mathrm{x}$ & II \\
\hline Cyclotella/Discotella spp. & 218.7 & 227.5 & 490.0 & 317.2 & 138.3 & 1031.2 & I \\
\hline $\begin{array}{l}\text { Skeletonema potamos (Weber) } \\
\text { Hasle }\end{array}$ & 437.7 & 1507.3 & $\mathrm{x}$ & 733.8 & $\mathrm{x}$ & 524.1 & $\mathrm{I}$ \\
\hline $\begin{array}{l}\text { Stephanodiscus parvus Stoerm. \& } \\
\text { Hakansson }\end{array}$ & 380.4 & 197.8 & - & - & 389.7 & 551.0 & $\mathrm{I}$ \\
\hline Other diatoms & 147.6 & $\mathrm{x}$ & 64.6 & 151.6 & $\mathrm{x}$ & $\mathrm{x}$ & II-IV \\
\hline
\end{tabular}


Carteria spp.

Chlamydomonas spp.

Pteromonas aculeata Lemmerm.

Other Chlorophyta

\begin{tabular}{ccccccc}
444.2 & $\mathrm{x}$ & - & 866.5 & - & - & $\mathrm{IV}$ \\
$\mathrm{x}$ & $\mathrm{x}$ & 82.1 & $\mathrm{x}$ & 89.0 & 332.6 & $\mathrm{II}$ \\
$\mathrm{x}$ & - & - & - & - & 2420.8 & $\mathrm{IV}$ \\
119.7 & $\mathrm{x}$ & 125.5 & 195.4 & $\mathrm{x}$ & $\mathrm{x}$ & $\mathrm{II}-\mathrm{IV}$ \\
$\mathrm{x}$ & & & & & & $\mathrm{IV}$ \\
& $\mathrm{x}$ & 54.9 & 228.9 & $\mathrm{x}$ & 520.6 & $\mathrm{II}$ \\
$\mathrm{x}$ & $\mathrm{x}$ & 64.7 & $\mathrm{x}$ & 172.5 & $\mathrm{x}$ & $\mathrm{IV}$ \\
$\mathrm{x}$ & $\mathrm{x}$ & - & $\mathrm{x}$ & 132.5 & $\mathrm{x}$ & $\mathrm{IV}$ \\
$\mathrm{x}$ & 317.7 & 98.9 & 160.7 & $\mathrm{x}$ & $\mathrm{x}$ & $\mathrm{III}$ \\
\hline
\end{tabular}

886

\section{Cryptophyta}

Cryptomonas erosa Skuja

Pyrrhophyta

Peridinium spp.

Chrysophyta

Cyanobacteria 
887 Table 5. Biomass of planktonic algae (\% of total biomass is shown in parentheses)

888 belonging to each of the four clusters of algal taxa (Fig. 4) found in four classes ( $\mu$ g Chl-

$889 a \mathrm{~L}^{-1}$ ) of samples derived from regression tree analysis and defined by discharge (mean

890 daily $\mathrm{Q}$ three days before sampling, $\mathrm{m}^{3} \mathrm{~s}^{-1}$ ) and light (mean hourly PAR three days before

891 sampling, $\mu \mathrm{mol} \mathrm{m} \mathrm{s}^{-1}$ ) (Fig. 7).

892

Classes of samples ( $\mu \mathrm{g}$ Chl- $\left.a \mathrm{~L}^{-1}\right)$ defined by discharge (Q) and light (PAR) conditions

\begin{tabular}{|c|c|c|c|c|}
\hline & $\begin{array}{c}1 \\
Q \geq 44\end{array}$ & $\begin{array}{c}2 \\
Q<15\end{array}$ & $\begin{array}{c}3 \\
\text { Q } 15-43 \\
\text { PAR }<783 \\
\end{array}$ & $\begin{array}{c}4 \\
\text { Q } 15-43 \\
\text { PAR } \geq 783 \\
\end{array}$ \\
\hline $\begin{array}{l}\text { Mean ( } \pm \text { s.d. }) \\
\text { Chlorophyll- } a \\
\text { concentration in model } \\
\left(\mu \mathrm{g} \mathrm{Chl}-a \mathrm{~L}^{-1}\right)\end{array}$ & $\begin{array}{c}6.4 \\
\pm 7.8\end{array}$ & $\begin{array}{l}23.3 \\
\pm 9.9\end{array}$ & $\begin{array}{c}27.6 \\
\pm 14.9\end{array}$ & $\begin{aligned} & 51.6 \\
\pm & 20.92\end{aligned}$ \\
\hline \multicolumn{5}{|l|}{$\begin{array}{l}\text { Mean biomass }\left(\mu g \mathrm{~L}^{-1}\right) \\
(\%)\end{array}$} \\
\hline $\begin{array}{l}\text { Cluster I } \\
\text { (Dominant centric } \\
\text { diatoms) }\end{array}$ & $\begin{array}{c}350.1 \\
(40)\end{array}$ & $\begin{array}{l}779.7 \\
(41)\end{array}$ & $\begin{array}{c}1668.6 \\
(65)\end{array}$ & $\begin{array}{l}3235.3 \\
(65)\end{array}$ \\
\hline $\begin{array}{l}\text { Cluster II } \\
\text { (Mixed algae from five } \\
\text { taxonomical groups) }\end{array}$ & $\begin{array}{c}392.4 \\
(45)\end{array}$ & $\begin{array}{c}793.5 \\
(42)\end{array}$ & $\begin{array}{c}661.3 \\
(26)\end{array}$ & $\begin{array}{l}1393.5 \\
(28)\end{array}$ \\
\hline $\begin{array}{l}\text { Cluster III } \\
\text { (Cyanobacteria) }\end{array}$ & $\begin{array}{c}5.7 \\
(<1)\end{array}$ & $\begin{array}{l}33.2 \\
(2)\end{array}$ & $\begin{array}{l}33.7 \\
(1)\end{array}$ & $\begin{array}{l}128.6 \\
(3)\end{array}$ \\
\hline $\begin{array}{l}\text { Cluster IV } \\
\text { (Mixed Chlorophyta, } \\
\text { Chrysophyta and } \\
\text { Pyrrhophyta) }\end{array}$ & $\begin{array}{c}130.9 \\
(15)\end{array}$ & $\begin{array}{c}282.9 \\
(15)\end{array}$ & $\begin{array}{l}205.9 \\
(8)\end{array}$ & $\begin{array}{c}203.1 \\
(4)\end{array}$ \\
\hline $\begin{array}{l}\text { Total plankton biomass } \\
\left(\mu \mathrm{g} \mathrm{L}^{-1}\right)\end{array}$ & 879.1 & 1889.3 & 2569.6 & 4960.5 \\
\hline
\end{tabular}




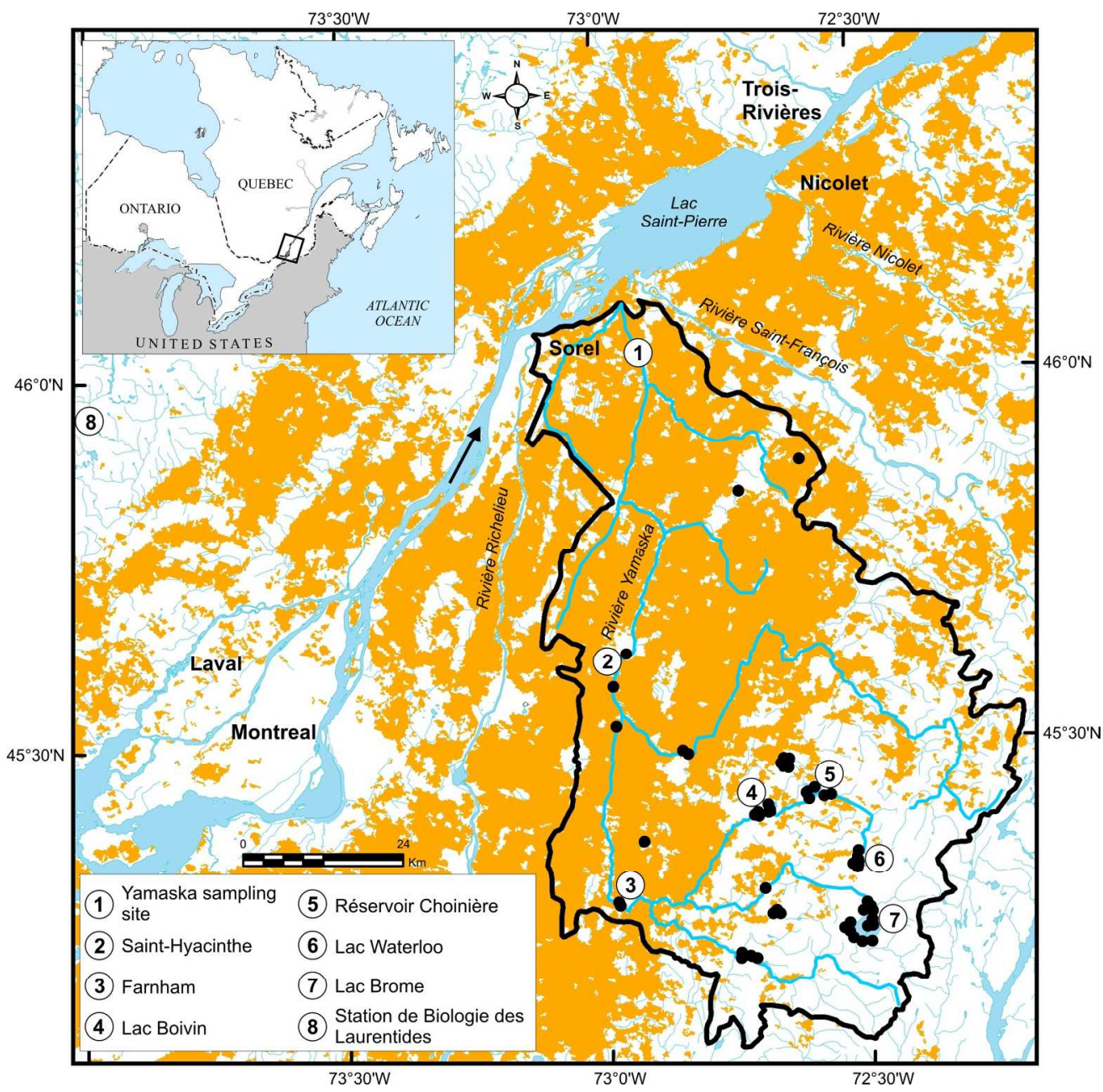

Figure 1. Map of Rivière Yamaska watershed (bold outline) in the St. Lawrence River Valley (inset), Quebec. The Rivière Yamaska flows into Lac Saint-Pierre downstream of Sorel. Other major tributaries and flow direction (arrow) of St. Lawrence River are also shown. Sampling sites are indicated in the lower Yamaska (No. 1), the towns of Saint-Hyacinthe (No. 2) and Farnham (No. 3), and lakes and reservoirs along the north (No. 4-6) and main (No. 7) branches of the Rivière Yamaska where hydrological conditions were characterized (see Table 1). Locations of cyanobacterial episodes reported by the public (2008-2012, MDDELCC 2016) in the Rivière Yamaska watershed are shown (full circles). The distribution of farmlands (shaded area) for 2010 was obtained from the North American Land Change Monitoring System (NALCMS) (available at https://landcover.usgs.gov/nalcms.php). The location of Station de Biologie des Laurentides (No. 8) is also indicated.

$187 \times 183 \mathrm{~mm}(300 \times 300 \mathrm{DPI})$ 


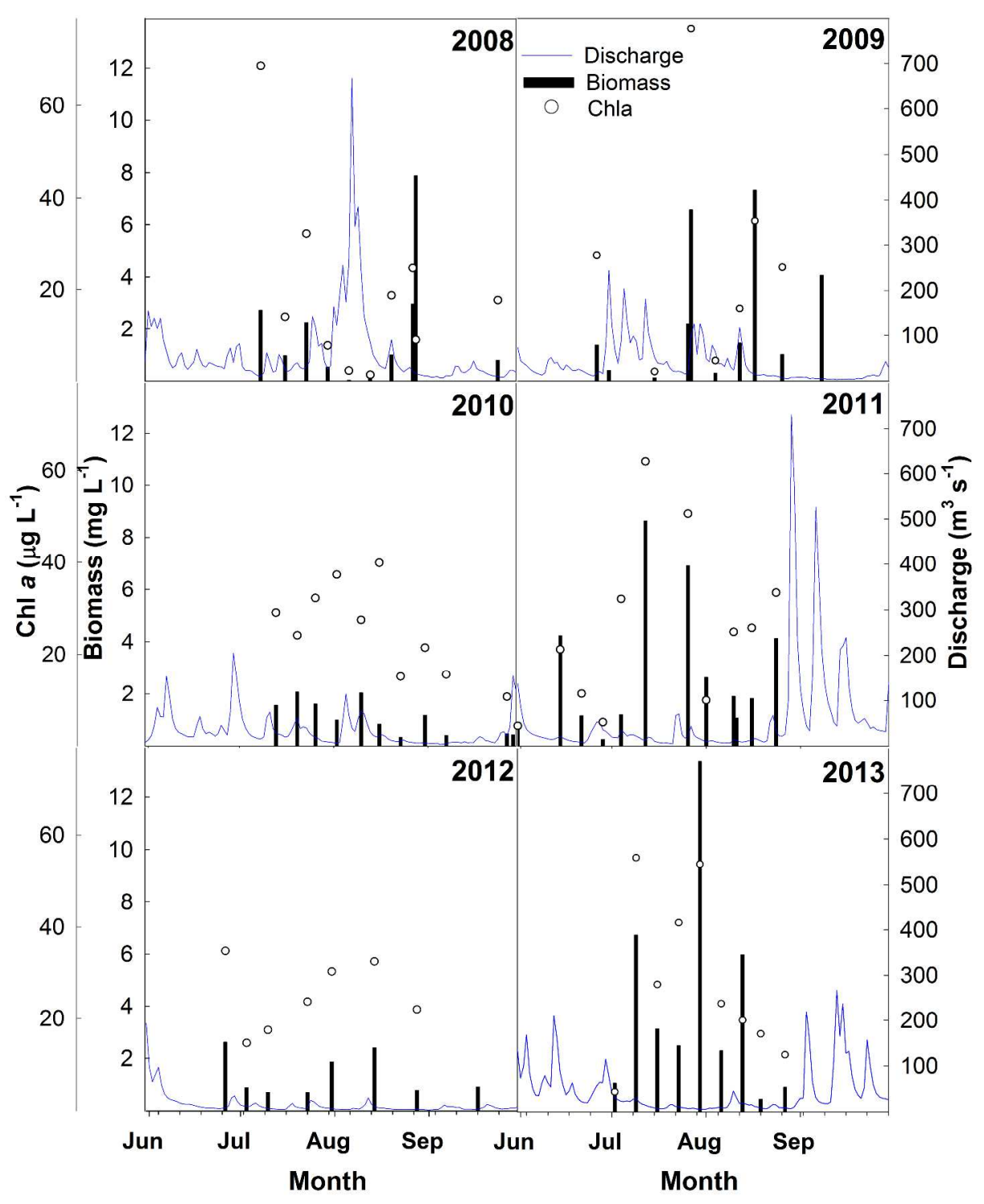

Figure 2. Temporal (2008-2013, Panels A to F) variations of plankton cell biomass (mg L $\mathrm{L}^{-1}$, inner left $\mathrm{Y}$-axis,

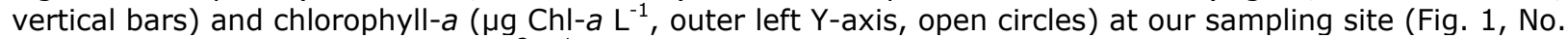
1) in conjunction with discharge $\left(\mathrm{m}^{3} \mathrm{~s}^{-1}\right.$, right $\mathrm{Y}$-axis, hairline) variations in the Rivière Yamaska downstream of Saint-Hyacinthe (Fig. 1 No. 2). Discharge data covers the same interval for each year; the name of each month is indicated at the beginning of each period. 


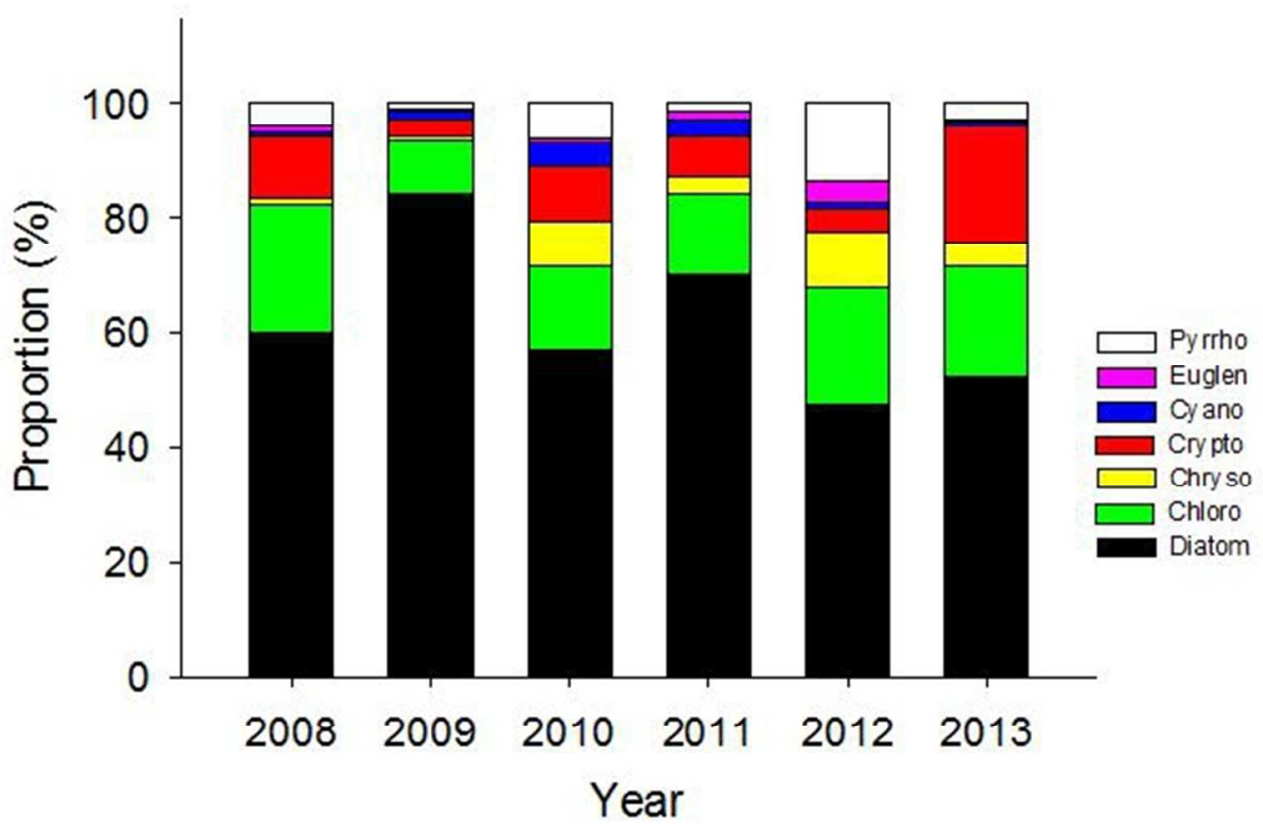

Figure 3. Relative abundance (proportion of total biomass) of each taxonomic group for each sampling season at our sampling site (Fig. 1, No. 1) in the Rivière Yamaska.

$129 \times 83 \mathrm{~mm}(120 \times 120 \mathrm{DPI})$ 


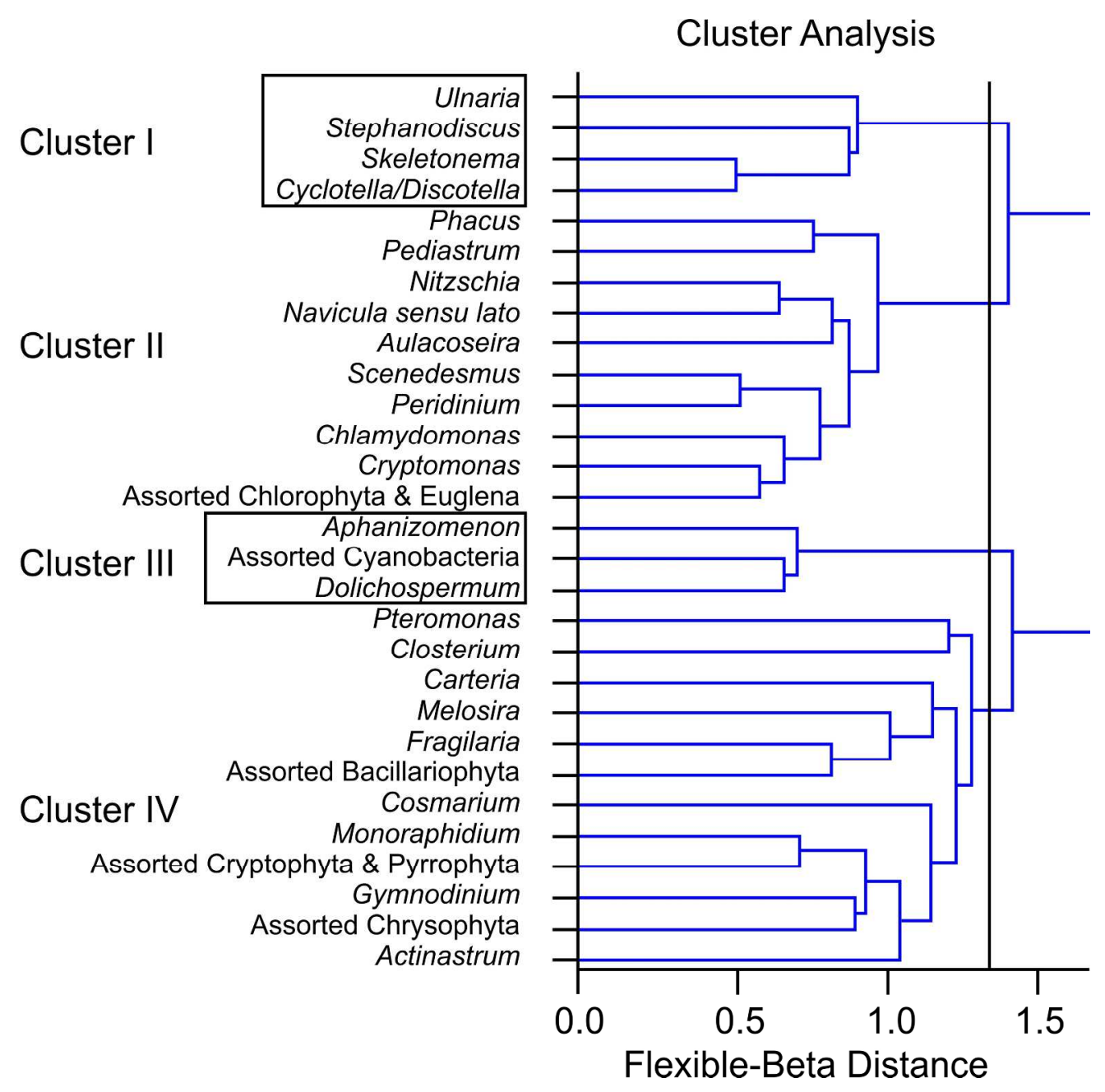

Figure 4. Cluster analysis of the relative abundance of major taxa in all Rivière Yamaska samples (Fig. 1, No. 1 ), using the Lance and Williams distance and flexible-beta clustering method. Four distinct groups (Clusters I-IV) were found to represent taxa dominating samples simultaneously, at a distance of 1.3 (vertical black line).

$244 \times 241 \mathrm{~mm}(300 \times 300 \mathrm{DPI})$ 


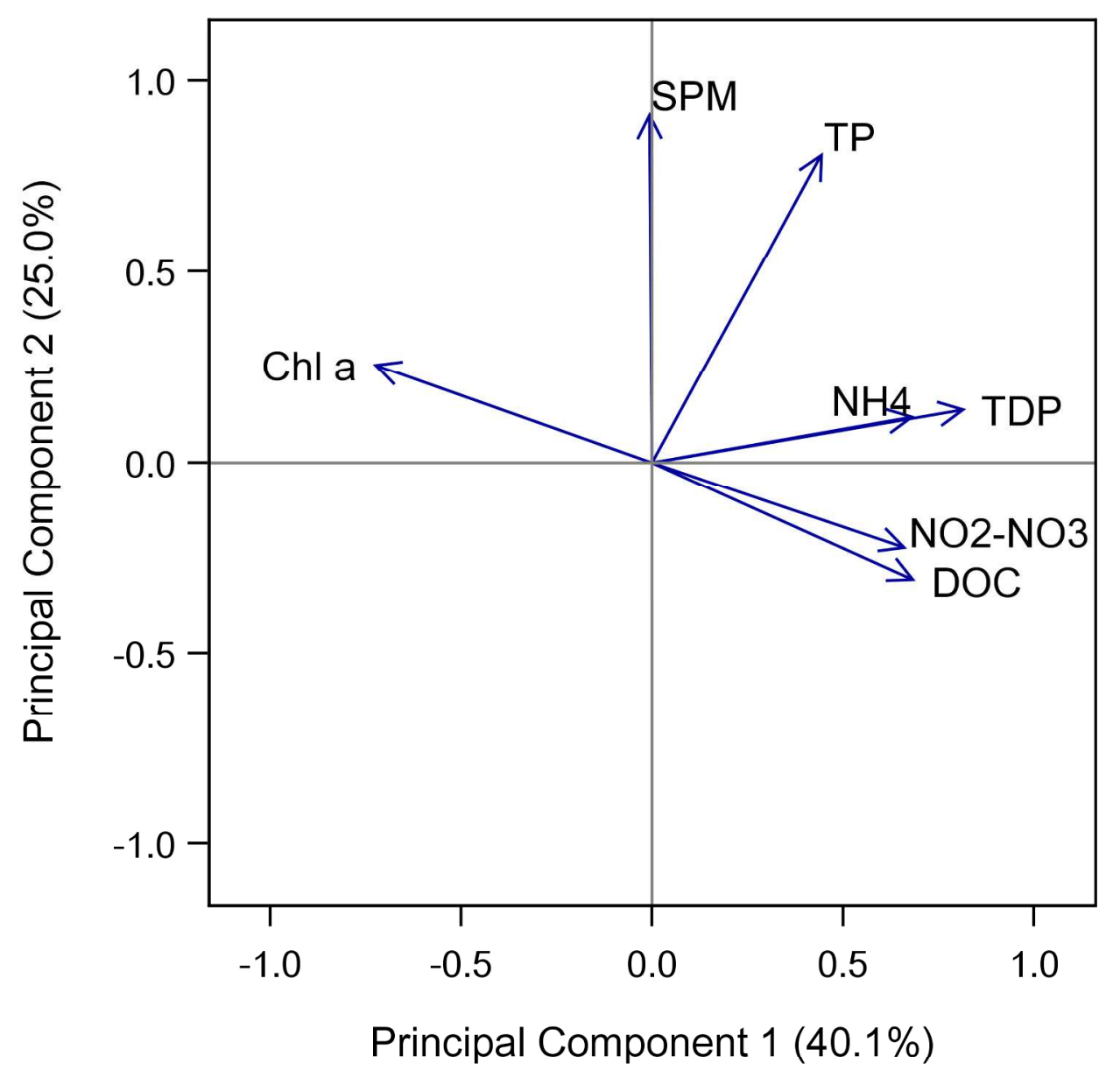

Figure 5. A: Correlations of principal components with constituent chemical variables measured at our sampling site (Fig. 1, No. 1) in the Rivière Yamaska (May 2008 - Aug. 2013, N = 50). 


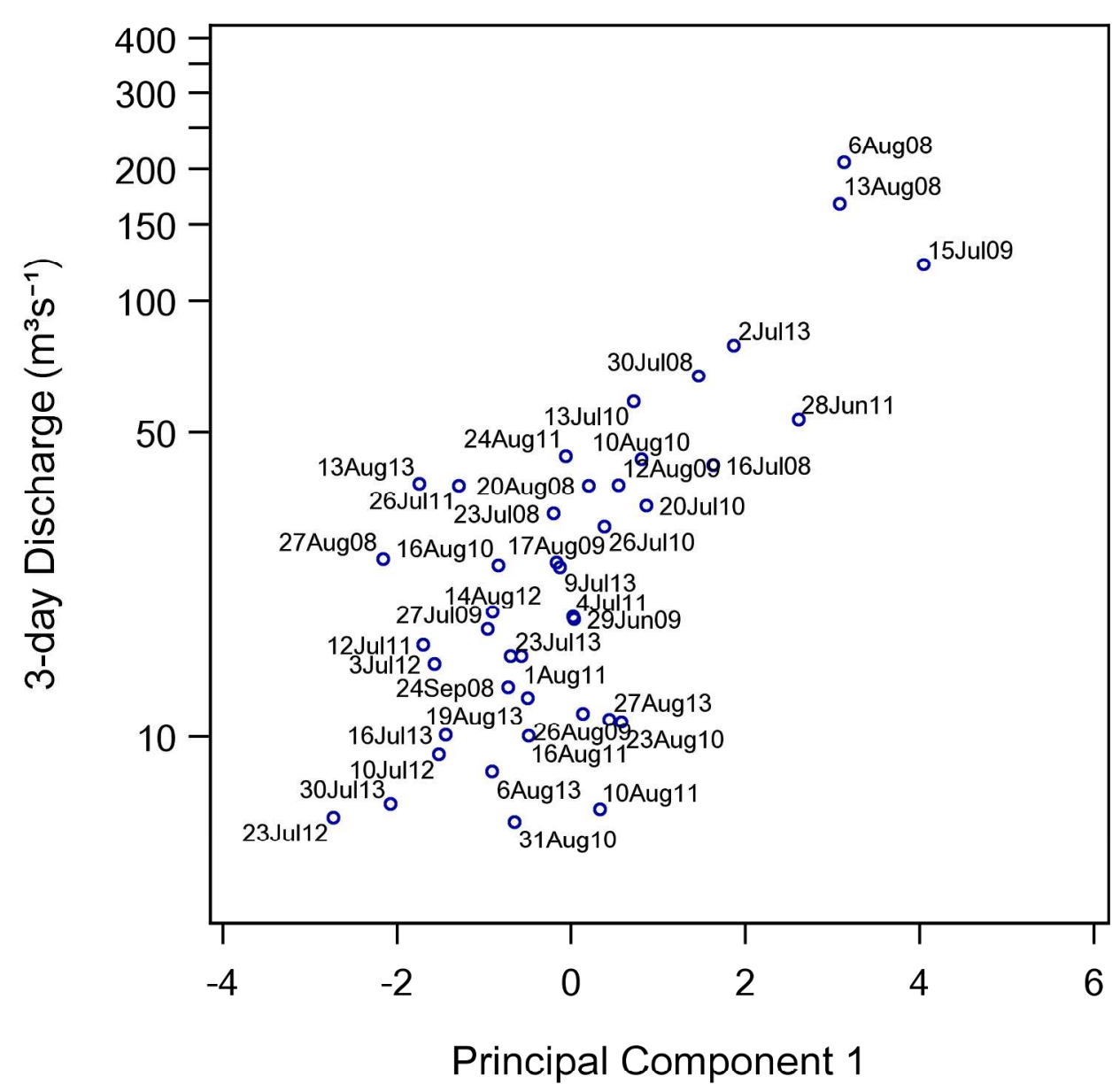

Figure 5. B: Correlation between the first principal component and the mean river discharge for the three days prior to sampling; sampling dates are represented. 


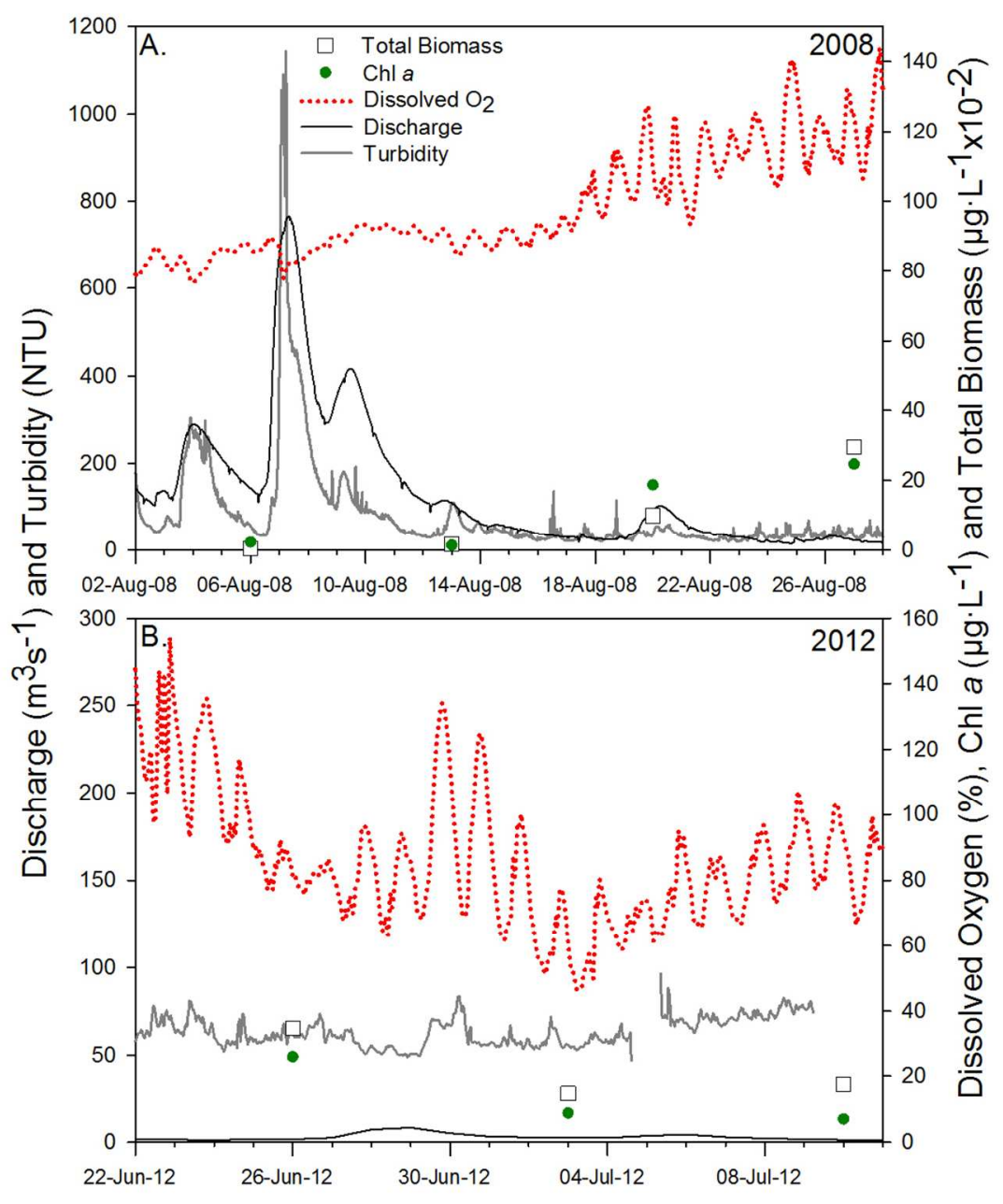

Figure 6. Hourly variations of water discharge (thin black line), turbidity (grey line) and dissolved $\mathrm{O}_{2}$ (bold dotted line) at our sampling site (Fig. 1, No. 1) in the Rivière Yamaska. Point measurements of chlorophyll-a concentration (full circles) and total biomass (open squares) are also indicated. A: Flash discharge events August 2-28, 2008. B: Stable low discharge period June 22 - July 11, 2012.

$215 \times 279 m m(150 \times 150 \mathrm{DPI})$ 


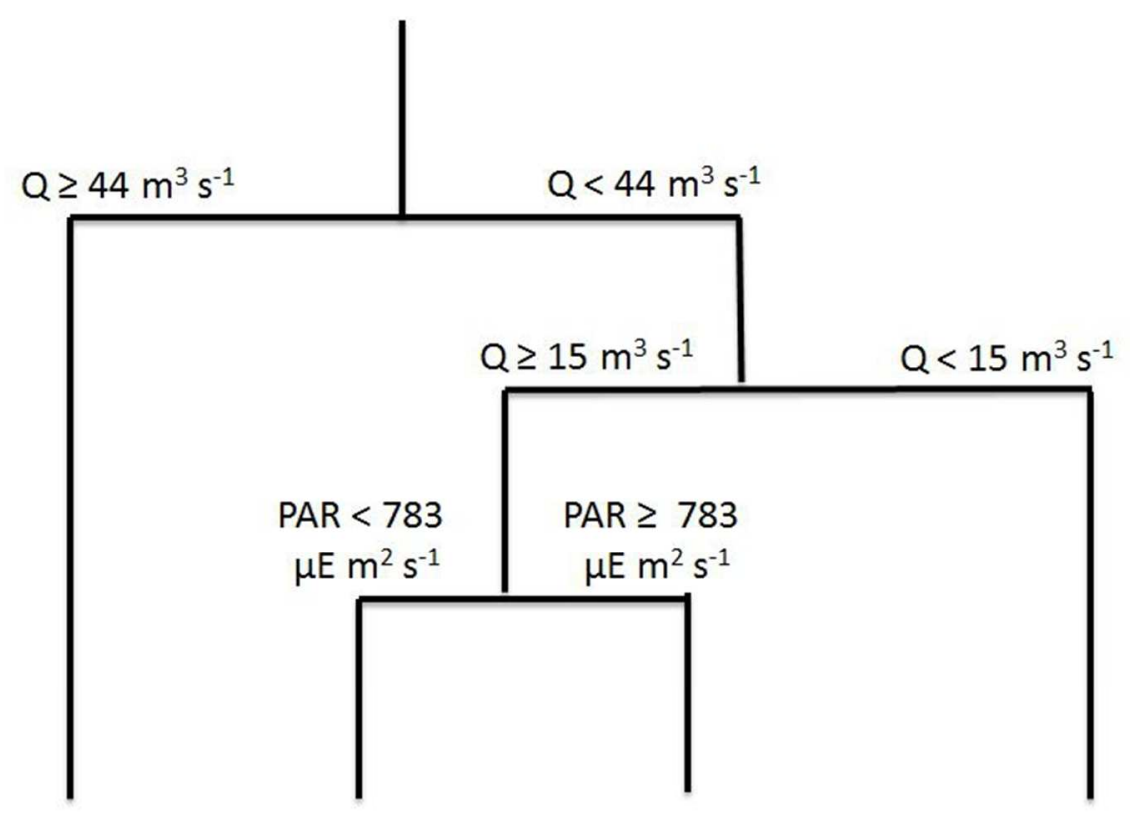
6. $4 \pm 7.8$
$27.6 \pm 14.9$
$51.6 \pm 20.9$
$23.2 \pm 9.9$
$\mathrm{N}=10$
$\mathrm{N}=21$
$\mathrm{N}=9$
$\mathrm{N}=20$

Figure 7. Hierarchical regression tree model predicting the concentration of planktonic chlorophyll-a ( $\mu \mathrm{g}$ Chl$a \mathrm{~L}^{-1}$ ) at our sampling site (Fig. 1, No. 1) in the Rivière Yamaska (2008-2013) from the mean river discharge (Q) and illumination (PAR) over the three days prior to sampling. For each branch of the tree, the mean \pm s.d. chlorophyll-a concentration $\left(\mu \mathrm{g} \mathrm{Chl}-a^{-1}\right)$ and the number of samples $(\mathrm{N})$ are specified; the model explains $59 \%$ of total variance in data.

$143 \times 103 \mathrm{~mm}(144 \times 144$ DPI) 